\title{
İctihad Farklılıklarının İtikâdî Boyut Kazanmasının Sonuçları Hâricîler Örneği
}

\section{Hasan GÜMÜŞOĞLU *}

\section{Özet}

Bu makalede ictihada dayalı faklılıklardan dolayı ortaya çıkan görüş ayrılıklarının itikâdî alana taşınmasının sonuçları araştırılmıştır. Konunun bütünlüğü açısından giriş kısmında ictihad hakkında kısa bir bilgi verildikten sonra itikâdî alanın sınırlarına dikkat çekilmiştir. Daha sonra Hz. Osman'ın şehit edilmesiyle sonuçlanan olaylar esnasında ilk tezahürleri görülmeye başlayan günahı sebebiyle bir Müslümanın öldürülmesinin mubah olduğu anlayışının, Haricîler tarafindan, kendi görüşlerine muhalif ictihatta bulunanları tekfir etme düşüncesine nasıl dönüştürüldüğü incelenmeye çalışılmıştır. Son kısımda ise Hâricîlerin bu yaklaşımının Kur'an ve Sünnet'e dayalı İslam anlayışından bir kopuş olduğu ve Müslümanlar tarafindan genel manada kabul görmediği ifade edilmiştir.

Anahtar kelimeler: İctihad, İtikad, İhtilaf, Tekfir

\section{The Results Of The Differences In Ijtihad After They Took A Theological Dimension: The Example: Kharijistes}

\section{Abstract}

In this article, the results of the differences in point of view that appeared as a consequence of the differences in ijtihad after they were carried into theological area has been researched. For the unity of the subject first abrief information has been given about the term ijtihad and then its theological boundaries have been underlined.

Afterwards; how the understanding of the allowablity of killing a muslim because of his/her sin that was first seen after the incidents that resulted in the martyrdom of Osman b. Affan was evolved into the thought of takfir by Kharicites for whom made an ijtihad in opposition to their views was tried to be analysed. In the last section; it was stated that this approach of the Kharicites was

* Yrd. Doç. Dr., Yalova Üniversitesi İslami İlimler Fakültesi, hasgumus@homail.com 
a disengagement from the Islamic understanding based on Quran and Sunnah and wasn't accepted generally by the Muslims.

Keywords: Differences in ijtihad, Theology, Belief, Kharijites

\section{Giriş}

\section{İctihad Farklılıklarının Dinî ve Sosyal Zemini}

Lügat itibariyle, elinden gelen gayreti gösterip, bütün gücünü harcamak manasına gelen ve yapılan meşakkatli, zor işleri ifade için kullanılan $^{1}$ ictihad, sstılahta, fakihin şer'i bir hüküm hakkında zan hasıl olması için bütün gücünü harcaması şeklinde tarif edilmiştir. ${ }^{2}$ Ebû Bekir Ahmed el-Cessâs (370/981), ictihadın örfte, hakkında istenilen bir bilgiye ulaştıracak şekilde, Allah Teâlâ katından bir delil bulunmayan olayların hükümlerinin verilmesine tahsis edildiğini belirtmiş ve ictihad ile elde edilen hükmün zannî, Allah katından delil ile elde edilen hükmün ise katî olduğuna dikkat çekmiştir. ${ }^{3}$

Kur'ân-1 Kerim, İslâmî hükümlerin kaynağı olmakla birlikte vahyin bulunmadığı meselelerde Hz. Muhammed'in (s.a.v.) sünneti ve ictihadı belirleyici olmuştur. İbn Hazım (ö.456/1064) ve Mu’tezile'den bazıları, Hz. Muhammed'in (s.a.v.) ictihad etmediğini söylemiş ${ }^{4}$ ise de, âlimlerin büyük ekseriyeti, onun ictihad ettiğini ifade etmişlerdir. ${ }^{5} \mathrm{~Hz}$. Peygamberin Bedir Harbi sonrasında esirlere uygulanacak hüküm hususunda ashâbıyla

1 Gazzâlî, Ebû Hamid, el-Müstasfâ min ilmi'l-usûl, nşr. Hamza b. Züheyr Hâfız, Medine, 1993, IV, 4; Râzî, Fahreddîn Muhammed b. Ömer b. Hüseyn, el-Mahsûl fí ilmi usûlü'l-fikh, nşr. Tâhâ Câbir Feyyâz el-Ulvânî, Beyrut 1992, VI, 6; Âmidî, Seyfüddîn Ali b. Muhammed, el-Ihkâm fî̀ usûli'l-ahkâm, nşr. Abdurrazzâk Afîfî, Riyad 2003, IV, 197.

2 Cürcânî, Seyyid Şerîf, et-Ta 'rifât, nşr. Abdurrahmân Umeyra, Beyrut 1987, s. 31; Teftâzânî, Sa 'duddîn Mes ud b. Ömer, Serhu't-Telvîh, alâ 't-Tevzîh li Metni't-Tenkîh, Dâru'l-kütübi'l-ilmiyye, Beyrut ty., II, 245; Güzelhisârî, Mustafa Hulûsî, Menâfiü'd-dekâik fî şerhi Mecâmii'l-hakâik li Muhammed el-Hâdimî̀, İstanbul 1273, s. 300.

3 Cessâs, Ebû Bekr Ahmed b. Alî er-Râzî, el-Füsûl fi'l-usûl nşr. Uceyl Câsim en-Neșemî, Kuveyt 1994, IV, 11, 18.

4 İbn Hazm, el-îhkâm fì usûli'l-ahkâm, nşr. Ahmed Muhammed Şâkir, Kahire ts., VIII, 134; Bağdâdî, Ebû Mansûr Abdulkâhir b. Tahir et-Temimî, el-Fark beyne'l-firak, Beyrut 1990, s.132; Râzî, el-Mahsûl fî̀ ilmi usûlü'l-fikh, VI, 73.

5 Serahsî, Şemsüleimme, Ebû Bekr Muhammed b. Ebî Sehl Ahmed, Usûlü 's-Serahsî, nşr. Ebu'l-Vefầ el-Efgânî, Beyrut 1993, II, 91-6; Bağdâdî, el-Fark beyne'l-firak, s. 132; Kâdı Abdülcebbâr, Şerhu'l-usûli'l-hamse, Beyrut 2001, s. 33; Râzî, el-Mahsûl fí ilmi usûlü'l-fikh, VI, 73, Âmidî, el-İhkâm fî usûli'l-ahkâm, IV, 200-212; Molla Hüsrev, Mirâtü'l-Usûl, İstanbul 1310, II, 5 . 
istişare etmesi ve neticede esirlerin fidye mukabilinde serbest bırakılması onu ictihadına örnek gösterilmiştir. ${ }^{6} \mathrm{~Hz}$. Peygamber'in bu ictihadı sonra gelen âyetlerle ${ }^{7}$ tashih edilmekle birlikte ictihad yasaklanmamıştır. Ayrıca Hz. Resûlullâh (s.a.v.) Muâz b. Cebel'i (r.a.) Yemen'e gönderirken nas1l hüküm vereceğini sormuş ve onun "Kitap ve Sünnet'te bulunmayan meseleler hakkında kendi görüşüyle ictihad edeceğini” ifade etmesinden memnun olmuştur. ${ }^{8}$

Asr-1 saâdet'te sahâbe arasında bazen ictihad farklılığg ortaya çıkmış ve her sahâbî kendi ictihadıyla amel etmiştir. Hendek Harbi'den sonra Peygamber Efendimiz; "Herkes ikindi namazını Benî Kurayza'da kılsın" şeklinde Medine'de ilan yaptırmıştı. Bu ilanı duyup yola çıkan sahâbîlerin bir kısmı ikindi namazını kaçırmamak için yolda kılmış, bir kısmı da namazın vakti geçtikten sonra Benî Kurayza’ya varınca kılmıştı. Bu iki fark1 ictihattan Resûlullah (s.a.v.) haberdar olunca, onların yaptığının yanlış olduğunu söylememiş ${ }^{9}$ veya bu yapılanların hata olduğunu beyan eden bir vahiy gelmemiştir. ${ }^{10}$ Sahâbîlerin bazısı "Hz. Peygamber namazın geçmesini istemez, bizim bir an önce Benî Kurayza'ya varmamızı istemiştir” şeklinde düşünüp, namazlarını yolda kılma ictihadında bulunmuşlardır. Bir kısmı ise, Resûlullah'ın emrini, ikindi namazının sadece Benî Kurayza'da kılınabileceği şeklinde anlayarak, namaz vakti geçmiş bile olsa daha sonra kılma yönünde ictihad etmişlerdir.

Resûlullâh'tan (s.a.v.) sonra sahâbîler, Kur'an-1 Kerim'de bulunmayan bir mesele ile karşılaştıklarında, öncelikle bu hususta Hz. Peygamber'in bir sünnetinin olup olmadığını araştırmışlardır. Nitekim Hz. Peygamber'in (s.a.v.) vefatından sonra onun nereye defnedileceği konusunda ashap arasında farklı görüşler dile getirilmiş ancak, "Peygamberler vefat ettikleri yere defin olunurlar" hadisi zikredilince tartışmalar bitmiş

6 Mâtürîdî, Ebû Mansûr Muhammed, Te vîllâtü Ehli s-sünne, nşr. Fatıma Yusuf el-Hıyamî, Beyrut 2004, II, 371; Kurtubî, Ebû Abdullah Muhammed b. Ahmed, el-Câmi 'li-ahkâmi 'l-Kur'ân, Beyrut 2006, IX, 72-73; Râzî, el-Mahsûl fì ilmi usûlü'l-fikh, VI,10.

7 Enfâl, 8/67-68.

8 Tirmizî, "Ahkâm", 3; Ebû Dâvûd, "Edebü'l-kâdî", 11; İbn Hanbel, Müsned, V, 230; Dârimî, Sünen, "Mükaddime", 20; el-Beyhakî, Ebû Bekr Ahmed b. Hüseyn b. Ali, es-Sünenü 'l-kübrâ, "Edebü'l-kâdî", Hindistan 1355, X, 114; Tabarânî, Ebü'l-Kâsım Müsnidü'd-dünyâ Süleymân b. Ahmed b. Eyyûb, Mu'cemü'l-kebîr, nşr. Hamdî Abdülmecid es-Selefî, Kahire ts., XX, 170.

9 Buhârî, "Meğâzî", 30.

10 İbn Hişâm, es-Sîretü'n-Nebeviyye, nşr. Mecdî Fethî es-Seyyid, Tanta 1995, III, 222 (1379).

YIL: 6 SAYI: 11 
ve Resûlullah (s.a.v.) Hz. Aișe'nin (r.a.) odasına defnedilmiştir. ${ }^{11}$ Aynı şekilde Hz. Peygamber'in geride bıraktığı malının miras hukukuna göre varislerine verilip verilmeyeceği mevzuunda da ihtilaf çıkmış, ancak Hz. Ebû Bekir (r.a.), bazı sahâbîlerin rivayet ettikleri; "Biz peygamberlere varis olunmaz. Bizim biraktıklarımız sadakadır"12 hadisini dikkate alarak, Hz. Peygamber'in malını varisleri arasında taksim etmemiştir. ${ }^{13}$

Gerçekleştirilen fetihler neticesinde İslâm coğrafyası genişleyip, yeni pek çok mesele ortaya çıkmış ve her mesele hakkında nastan delil getirmek mümkün olmamıştır. Zira naslar sınırlı, meydana gelen olaylar ve meseleler ise sınırsızdı. ${ }^{14} \mathrm{~Hz}$. Ömer, Kâdı Şureyh'e yazdığı mektupta bir mesele hakkında öncelikle Allah'ın kitabına bakmasını, onda bulunmayan meselelerde Sünnet'e müracaat etmesini, onda da bulamaz ise sahâbenin üzerinde icmâ ettiği bir görüş varsa onunla hüküm vermesini istemiştir. Hz. Ömer, Kâdı Şureyh'e, insanların hiç görüş beyan etmediği bir mesele kendisine geldiğinde ise, kendi görüşüyle ictihad ederek, hüküm verebileceğini veya (halifeye danışmak üzere) tehir edebileceğini bildirmiştir. ${ }^{15}$ Hz. Ömer, Ebû Mûsa el-Eş'arî'ye gönderdiği mektupta ise Kur'an ve Sünnet'te bulamadığ 1 meseleler hakkında emsal hadiseleri bulmaya çalışarak, kıyas yapmasını yani ictihad yapmasını istemiştir. ${ }^{16}$

Sahâbe devrinde Müslümanlar pek çok yeni mesele ile karşı karşıya kaldıkları için ictihad faaliyetleri gelişmiş ve ictihada mahal olan mevzularda her müctehidin aynı görüşe sahip olması, bir mecburiyet olarak görülmemiştir. ${ }^{17}$ Ebû Bekr Ahmed el-Cessâs ve Şemsüleimme es-Serahsî (ö.483/1090) gibi meșhur fakihlerin aralarında bulunduğu pek çok âlim,

11 İbn Hişam, es-Sîretü'n-Nebeviyye, IV, 373 (2107); el-Beyhakî, Ebû Bekr Ahmed b. Hüseyin, Delâilü̈'n-nübüvve, nşr. Abdülmu'tî Kal'acî, Kahire 1988, VII, 260.

12 Buhârî, "Humus", 1, "Nafakat", 3, Müslim, "Cihad", 49,56.

13 Nesefî, Ebü'l-Muîn Meymun b. Muhammed, Tebsıratu'l-edille fì usûli'd-dîn, nşr. Claude Salâme, Dımașk, 1993, II, 862; Bağdâdî el-Fark beyne'l-firak, s. 15-6; Şehristânî, Ebu'l-Feth Muhammed b. Abdilkerîm, el-Milel ve'n-nihal, nşr. Abdulemîr Ali Mehnâ-Ali Hasan Fâ ur, Beyrut 1993, I, 31-3.

14 Serahsî, Șemsüleimme Ebû Bekr Muhammed b. Ebî Sehl Ahmed, el-Mebsût, Beyrut 1989, XVI, 62-3; İbn Haldun, Abdurrahman b. Muhammed, Mukaddime, Beyrut 1992, s. 445-6; Şehristânî, el-Milel ve'n-nihal, I, 236.

15 Dârimî, Sünen, "Mukaddime” 20; İbn Abdilber, Ebû Ömer Yusuf, Câmiu beyâni 'l-ilm ve fazlihi, nşr. Ebu'l-Eşbâl ez-Züheyrî, Demmam 1994, II, 847.

16 Serahsî, Usûlü 's-Serahsî, I, 315.

17 Şâfî̂, Ebû Abdullâh Muhammed b. İdris, el-Üm, nşr. Rif'at Fevzî Abdülmuttalib, Mensûre 2001, VIII, 391 vd.; Âmidî, el-İhkâm fì usûli’l-ahkâm, IV, 227-8. 


\section{$134 \cdot$ YALOVA SOSYAL BILIMLER DERGISI}

sahâbe arasında ictihadî mevzularda meydana gelen ihtilafın, "sonraki Müslümanlar için farklı tercihlerde bulunmaya imkanı veren bir firsat" olduğu görüşünde birleşmişlerdir. Bu görüş birliğinin oluşmasında " $\ddot{U}$ mmetimin/ashâbımın ihtilafi rahmettir" ve "Ashâbım gökteki yıldızlar gibidir, hangisine uyarsanız hidayete ulaşırsınız"18 hadisleri esas alınmış ve onların her birinin ictihadının hak ve doğru olduğuna dikkat çekilmiştir. ${ }^{19}$ Ayrıca "Bir hâkim ictihad eder de verdiği hükümde isabet ederse iki mükâfat, hata ederse bir mükâfat vardır" ${ }^{20}$ hadisini dikkate alan âlimler, bir müctehidin hatasından dolayı kötülenmesini doğru bulmayıp, müctehidlerin bir mesele hakkında değişik hükümler vermesinin ümmet için bir rahmet olduğuna dikkat çekmişlerdir. ${ }^{21}$

\section{1. İtikâdî Konuların Çerçevesi}

Lügat itibariyle, bağlamak ve düğümlemek manasına gelen²2 "akd" kelimesinin iftiâl babına nakil edilmiş şekli olan "itikad”, inanma, kalben tasdik ve iman etme manalarına ${ }^{23}$ gelmekte ve düğüm atmış gibi bir şeye kalbiyle bağlanma ve inanmayı ifade etmektedir. ${ }^{24} \mathrm{Bu}$ sebeple kendisiyle amel değil de sadece inanılması (itikadı) kast olunana akîde, çoğuluna da akâid denilmiştir. ${ }^{25}$

İmam Mâtürîdî (ö.333/944), dinin itikad esaslarından meydana geldiğine işaret ederek, dinlere ait bu itikatların kalp vasıtasıyla oluşturuldu-

18 Beyhakî, Ahmed b. Hüseyin, el-Medhal ila's-Süneni'l-kübrâ, nşr. Muhammed Ziyâürahmân el-A'zamî, Riyad 1420, I, 148; Nevevî, Ebû Zekeriyyâ Yahyẩ b. Şeref, el-Minhâc fî şerhi Sahîhi Müslim b. Haccâc, Kahire 1930, XI, 91-2; Aclûnî, İsmâil b. Muhammed, Keşfü 'l-hafâ', Kâhire 1351, I, 64-66, 132; el-Münâvî, Muhammed Abdurraûf, Feyzü'l-kadîr şerhu'l-Câmiu's-sağîr, Beyrut 1994, I, 209

19 Cessâs, el-Füsûl fi'l-usûl, IV, 307; Serahsî, Usûlü 's-Serahsî, II, 107; Abdülazîz el-Buhârî, Keşfü'l-esrâr an Usûli Fahri'l-İslâm Pezdevî, nșr. Abdullah Mahmûd Muhammed Ömer, Beyrut 1997, III, 328-31; Âmidî, el-İhkâm fì usûli'l-ahkâm, IV, 233; Râzî, Fahreddîn Ebû Abdillah Muhammed b. Ömer, Mefâtihu'l-gayb, Beyrut ts., XXVII, 168; İbn Kudâme, Muvaffakuddîn el-Makdisî, Lüm 'atü'l-i 'tikâd, Beyrut 1395, s. 44; Âlûsî, Şihâbüddin Mahmud, Rûhu'l-Maânî, Beyrut 1998, XXV, s. 32; İbn Âbidîn, Muhammed Emîn, Reddü'l-muhtâr ale'd-Dürri'l-muhtâr şerh Tenvîri'l-ebsâr, nşr. Âdil Ahmed Abdülmevcûd-Ali Muhmmed Muavvız, Kâhire 1994, I, 167.

20 Buhârî, "İ'tisâm", 21; Müslim, "Akziye", 15; Ebû Dâvûd, "Akziye", 2.

21 Nevevî, el-Minhâc fì şerhi Sahîhi Müslim, XI, 92; İbn Âbidîn, Reddü'l-muhtâr, I, 139.

22 İbn Manzûr, Lisânü'l-Arab, Beyrut 1994, III, 296.

23 Şemseddîn Sâmî, Kâmus-ı Türkî, Dersaâdet 1317, I, 129.

24 Fîrûzâbâdî, Mecdüddîn Ebû Tâhir Muhammed b. Ya'kûb, Kâmus Tercemesi, trc. Asım Efendi, İstanbul 1304, I, 1215.

25 Cürcânî, et-Ta'rifât, s. 197; İsmail Hakkı İzmirli, Yeni İlm-i Kelâm, Dersaâdet 1330, s.7.

YIL: 6 SAYI: 11 
ğuna dikkat çeker. ${ }^{26}$ Kalbin kesin bağlanmasına taalluk etmesi ve âzalar ile amel kast olunmamasından dolayı Usûlü'd-dîn, akîde olarak isimlendirilmiş, kalpte itikad olmadan sadece dil ile iman esaslarını ifade etmenin münafıklık olduğu belirtilmiştir. ${ }^{27}$ Aralarında İmam Mâtürîdî, Ebû Bekir el-Bâkıllânî (ö.403/1013, İmâmü'l-Haremeyn el-Cüveynî (478/1085) ve Ebu'l-Muîn en-Nesefî (ö.508/1114) gibi meşhur kelâmcıların bulunduğu bir kısım İslâm ulemâsı imanın: "kalbin tasdikinden ibaret” olduğunu söyleyip, dil ile ikrarı, dünyevî hükümlerin uygulanması açısından zorunlu görmüşlerdir. ${ }^{28}$

İmâm Şâfiî, Mâlik, Ahmed b. Hanbel gibi bazı selef âlimleri ise, ameli imandan bir cüz kabul etmekle ${ }^{29}$ birlikte onların iman için tasdik ve ikrarı yeterli bulmayıp, uzuvlarla ameli zorunlu görmelerinin, kâmil bir mümin için geçerli olduğu söylenebilir. Zira onlar, ameli terk eden Müslümanın küfre gitmeyeceğini açıkça ifade etmişlerdir. ${ }^{30}$

Hz. Muhammed'in (s.a.v.) Allah katından getirdiği kesin olarak bilinen hususları kalbiyle tasdik eden, "mümin" kabul edilmekle birlikte buradaki iman, icmâlî bir imandır. Bir diğer tabirle Kelime-i Şehâdet'i veya Kelime-i Tevhid'i kalbiyle tasdik ederek söyleyen kimse, inanılması gereken hususları topluca kabul etmiş demektir. Gazzâlî, bu hususları hülasa ederek, imanın asıllarının üç olduğunu belirtmiş ve onların “Allah'a, Resulüne ve Âhiret gününe iman” olduğunu ifade etmiştir. ${ }^{31}$ Nitekim Kelâm âlimleri de itikadî mevzuları daha çok İlâhiyyât, Nebeviyyât, Sem'iyyât (âhirete taalluk eden hususlar) olmak üzere üç esasa irca ederek incelemişlerdir. ${ }^{32}$

26 Mâtürîdî, Ebû Mensûr Muhammed, Kitâbü 't-Tevhîd, nşr. Fethullâh Huleyf, İskenderiye ts. s, 377.

27 Bâbertî, Ekmelüddîn Muhammed, Serhu Akideti Ehli's-sünne ve'l-cemâ'a (Akîdetü'tTahâviyye), nşr. Arif Aytekin, Kuveyt 1409, s. 23, 23.

28 Mâtürîdî, et-Tevhîd, s. 380-81; Eş'arî, Ebu'l-Hasen, el-Lüma', Kahire ts. s. 122; Bâkıllânî, Kâdı Ebû Bekir Muhammed b. et-Tayyib, et-Temhîd, nșr. İmâdüddîn Amed Haydar, Beyrut 1987, s. 389; Bağdâdî, Usûlü'd-dîn, Beyrut 1981, s. 247-9; Cüveynî, Ebû'l-Meâli İmâmu'l-Haremeyn Rüknüddîn, el-İrşâd ilâ kavâtı '̀ l-edille fî usûli'l-i 'tikâd, nşr. Esad Temimî, Beyrut 1992, s. 333; Nesefî, Tebsiratu'l-edille, II, 799.

29 Nesefî, Tebsira, II, 798; Teftazânî, Sa 'du'd-dîn Mes ud b. Ömer, Şerhu'l-Akâid, Dersaâdet 1326, s. 180.

30 İbn Ebî Ya'lâ, Ebû Hüseyn Muhammed, Tabâkâtu'l-Hanâbile, nșr. Abdurrahmân b. Süleymân, Riyad 1419, s. 57-8; el-Lâlekâî, Hibetullah b. el-Hasen b. Mensur, Şerhu-usûli-i tikâdu Ehli's-sünne ve'l-cemâa, Beyrut 2007, s. 94-6.

31 Gazzâlî, Ebû Hamid, Faysalü t-tefrika, Beyrut 1994, s. 89.

32 İmam-1 Âzam, Ebu Hanife, el-Fikhu'l-ekber, nşr. Mustafa Öz, İstanbul 1992, s. 70; el-Fık- 


\section{$136 \cdot$ YALOVA SOSYAL BILIMLER DERGISI}

Ehl-i sünnet kelamcılar, altı şartta öz olarak ifade edilen esasların açıklaması olan ve "zarûrât-1 diniye", olarak ifade edilen hususların hepsine iman edilmesini sahih bir itikad için lüzumlu görmüşlerdir. Bu itibarla sahih bir itikad için imanın şartlarının yanı sıra Hz. Muhammed'den (s.a.v.) tevâtüren sabit olan namaz, zekât oruç, hac ve zekâtın farziyeti; içki ve kumarın haramlığı gibi hususlara inanılması zarurîdir. ${ }^{33}$ İman, Hz. Muhammed'in (s.a.v.) Allah katından getirdiği hususların hepsini kalp ile tasdik manasına geldiğinden imanın bölünmesi (tecezzi) mümkün olmayıp, bu hususlardan birini inkârın, hepsini inkâr manasına geldiği ifade edilmiştir. Dolayısıyla imanın gerçekleşmesi için Hz. Peygamber'in getirdiği esasların hepsinin tasdik edilmesi zorunlu olduğundan ${ }^{34}$ sübutu ve delaleti katî olan bir konunun itikâdî bir mesele olarak kabul edilmesi ve bu esasın dışında kalan hususların itikâda dahil edilmemesi ehemmiyet arz etmektedir. $^{35}$

Bir meselenin fikhî değil de itikadî olması durumunda hükmünün tamamen değişeceğine işaret eden İbn Kuteybe, fikhî konularda ihtilafı meşru görmekle birlikte, itikadî konularda ihtilaf etmenin bir mazeretinin olmayacağını şöyle ifade etmiştir:

"Eğer onların (kelamcıların) ihtilafları (itikatta değil de) sünnetlerde ve furu'da olsa idi (kendileri için iddia ettikleri şeylerde mazeretleri olmasa da) bize göre fikıh ehlinin mazereti olduğu gibi onların da mazereti olur, onlarla aynı durumda olurlardı. Fakat onların ihtilafi, Allah'ın sıfatları, kudreti, cennet ehlinin nimetleri, cehennem ehlinin azab1, kabir azab1, Levh-i mahfûz ve bunlara benzer, ancak bir peygamberin vahiy yoluyla bildiği hususlarda olmuştur." 36

İtikâdî mevzuların tespiti meselesinde bir dinin esasını teşkil eden

hu'l-ebsat, nşr. Mustafa Öz, İstanbul 1992, s. 45; Mâtürîdî, Kitâbü 't-Tevhîd, s. 304 vd; Eş'arî, Ebu'l-Hasen, el-íbâne an usûli'd-diyâne, nșr. Abbas Sabbağ, Beyrut 1994, s.151 vd; Bak1llânî, et-Temhîd, s. 367 vd; Nesefî, a.g.e., II, 715; Bağdâdî, a.g.e., s. 249.

33 Gazzâlî, Faysalü 't-tefrika, s. 78,89; Bağdâdî, a.g.e., s. 249; Şa'rânî, Abdulvahhâb b. Ahmed, el-Yevâkît ve'l-cevâhîr, Kahire, 1959, II, 123; Teftazânî, Şerhu'l-Akâid, s. 190; a.mlf., Şerhu'l-Makâsıd, nşr. Abdurrahman U 'meyrâ, Beyrut 1989, V, 228-9; Aliyyü'l-kârî, Şerhu'lFikhı'l-ekber, Beyrut 1984, s. 225-30; İmâm-1 Rabbânî, Mektûbât, İstanbul ts. III, 22.

34 Gazzâlî, Ebû Hamid, Kavîdü'l-akâid, Beyrut ts. s. 98.

35 Tevfik Yücedoğru, "İtikâdî İlkelerin Tespiti”, Selçuk Üniversitesi İlahiyat Fakültesi Dergisi, c. XIX, Bahar 2005, s. 51.

36 İbn Kuteybe, Ebû Muhammed ed-Dîneverî, Te 'vîlü muhtelifi'l-hadîs, nşr. Ebû Üsâme Selîm, Kahire 2009, s.79.

YIL: 6 SAYI: 11 
imana verilen mananın ve iman-amel ilişkisinin mühim bir yeri bulunmaktadır. Ameller, imana dahil edildiği takdirde itikad alanının sınırlarını çizebilmek oldukça zorlaşmaktadır. Yukarıda belirttiğimiz gibi selef ulemâsının bir kısmının imanı tarif ederken ikrar ve tasdikle beraber ameli de zikretmeleri; kanaatimizce ilk Müslümanların inandıklarının gereğini yerine getirme konusunda gösterdikleri başarının devamını sağlamaya yöneliktir. ${ }^{37}$ Zira Ahmed b. Hanbel, başta olmak üzere selef uleması, kıble ehlinden bir kimsenin günahı sebebiyle küfre nispet edilmesini ve İslâm dışına çıkarılmasını doğru bulmamıştır. ${ }^{38}$

Mu'tezile ve Havâric, ilâhî emirleri yerine getirmeyenlerin mümin olmadığ 1 konusunda hem fikir iken Mu’tezile, böyle bir kişinin imandan çıktığını ancak kâfir olmadığını (el-menzile beyne'l-menzileteyn) söylerken, Havâric, bu kimsenin kâfir olduğunu ifade etmiştir. ${ }^{39}$ Ehl-i sünnet ulemâs1 ise günahı sebebiyle bir Müslümanın tekfir edilmesini doğru bulmamıştır. Ehl-i sünnet ulemâsı, amelleri kâmil bir imanın alâmeti olarak görmüş ve günahların "Allah'ın haram kıldığı bir şeyin helal kabul edilerek" işlenmesi durumunda, tekfirin söz konusu olacağını söylemişlerdir. "Ístihlâl" terimi ile ifade edilen bu durumda, yapılan işin amel boyutundan daha çok inanç tarafı ön plana çıktığından istihlâl, kalpteki tasdiki ortadan kaldıran bir inanç değişikliği olarak görülmüş ve küfür sayılmıştır. ${ }^{40}$

Sahâbe devrinden itibaren Müslümanlar arasındaki siyasî görüş ayrılıkları veya amelî mevzulardaki ictihad farklılıkları sebebiyle Cemel ve Sıffin hâdiseleri yaşanmış olsa bile taraflar, genel manada birbirlerini küfre nispet etmekten kaçınmışlardır. Ancak, sadece belirli âyetleri şiar edinip, Kur'an-1 Kerim'i bir bütün olarak değerlendirmeyen ve Sünnet'e yeterince ehemmiyet atfetmemelerinden dolayı sınırlı ve dar bir çerçevede düşünüp karar veren Hâricîler tarafindan aynı anlayış ve yaklaşım benimsenmemiştir. Hâricîlerin, nasların değişik şekillerde anlaşılmasının

37 Hasan Gümüşoğlu, “İmanın Artması-Eksilmesi Meselesi ve Amel ile İlişkisi”, Diyanet İlmi Dergi, c. 44, Sy. II (2008), s. 138

38 İmâm-1 Âzam, Risâle ilâ Osman el-Bettî, nșr. Mustafa Öz, İstanbul 1992, s. 82; İbn Ebî Ya'lâ, Tabâkâtu'l-Hanâbile, s. 57-8; el-Lâlekâî, Şerhu-usûli-i'tikâdu Ehli's-sünne ve'l-cemâa, s. 946.

39 Bağdâdî, a.g.e. s.249; Cüveynî, a.g.e, s.333; Teftazânî, Şerhu'l-Makâsıd, V, 179-80.

40 Mâtürîdî, Kitâbü 't-Tevhid, s. 348; Mekkî, Ebû Tâlib, Kûtü'l-kulûb, Beyrut 1997, II, 209; Cürcânî, Seyyid Şerîf, Serhu'l-Mevâkıf, İstanbul ts, II, 458, Teftazânî, Şerhu'l-Makâsîd, V, 203; a.mlf., Şerhu'l-Akâid, s. 142-4; Aliyyü'l-kârî, Şerhu'l-Fıkhı'l-ekber, s. 226. 


\section{$138 \cdot$ YALOVA SOSYAL BILIMLER DERGISI}

bir tezahürü olan ictihadî ihtilafları reddeden ve bu konudaki farklılıklara tahammül göstermeyen tavrının itikadî alana çekilmesinin derin etkileri olmuştur.

\section{2. İctihad Faklılığını Reddetme ve Hz. Osman'ın Şehit Edilmesi}

Önceden ifade ettiğimiz şekilde sahâbe devrinden itibaren âlimler arasında bazı mevzularda ictihad farklılı̆̆ bunlar bir tefrikaya sebep olmak şöyle dursun söz konusu ihtilaflar, "Müslümanlara farklı tercihlerden biriyle amel etme imkanı veren bir firsat" olarak görülmüştür. Hulefâ-yi Râş̧idîn devrinden itibaren değişik inanç ve kültürlerden insanların İslam'a girmesinin ve fetihler sayesinde toplumun ekonomik refah seviyesinin oldukça yükselmesinin dinî ve dünyevî pek çok sonuçları olmuştur. Özellikle Hz. Osman'ın son döneminde, İslâm ülkesinde büyük bolluk meydana gelmekle birlikte bazı Müslümanların dünyaya fazla hevesli olmaları, makam ve mevki konusunda daha istekli bulunmaları, ihtilafların çıkmasına ve tartışmaların çoğalmasına sebep olmuştu. ${ }^{41}$

Müslüman olduğunu söyleyenlerin bir kısmı İslâm'ın kabul etmiş görünmekle birlikte, eski inançlarını tam olarak bırakmadan, bazı dinî metinleri kendi görüşleri veya menfaatleri doğrultusunda yorumlamışlar ve bunları insanlar arasında yaymaya çalışmışlardır. Bazı âlimler, böyle bir atmosferde ortaya çıkan İbn Sebe'nin fikir ve hareketleriyle toplumda huzursuzluğa sebep olmasına ve değişik şehirlere sürgün edilmesine dikkat çekmişlerdir. ${ }^{42}$

Özellikle yeni Müslüman olmuş ve İslâm'1 iyi bilmeyen kimseler arasında Hz. Osman aleyhinde geliştirilen düşüncelerin taraftar bulmasıyla çıkan kargaşa büyümüş ve bir kısım insanlar, Hz. Osman'ın bazı icraatlar1na karşı yaptıkları itirazlarını isyana dönüştürmüşlerdir. Bu şekilde Mısır, Basra ve Kûfe'den gruplar halinde insanlar, Medine'ye gitmek üzere yola çıkmıșlardı. Abdullah b. Sebe'nin gizli eliyle bir şekilde tahrik edildiği 41 Metin Bozkuş, "İslâm Mezhepleri Açısından Dini Düşüncenin Geçirdiği Evreler", Cumhuriyet Üniversitesi Illahiyat Fakültesi Dergisi, Sy., VI/I, 2002, s. 201.

42 et-Taberî Ebû Câfer Muhammed b. Cerir, Târihu'r-rusul ve'l-mülük, Kahire ts., IV, 340-1; İbnü'l-Esîr, İzzeddîn Ebi'l-Hasen Ali b. Ebi'l-Kasım eş-Şeybânî, el-Kâmil fi 't-târîh, Beyrut 1987, II, 251.

YIL: 6 SAYI: 11 
ifade edilen ${ }^{43}$ söz konu kalabalıklarla Medine'ye girmeden önce Hz. Ali başta olmak bazı sahâbîler görüşmüş ve Hz. Osman hakkında ileri sürülen ithamların doğru olmadığı konusunda onları ikna etmişlerdi. Söz konusu gruplar geldikleri beldelere geri dönmek üzere yola çıktıkları halde, hakkında farklı ve çelişkili rivayetler bulunan bir sebepten dolayı, geri dönüp Medine'yi işgal etmişler ve Hz. Osman'ı suçlayıp, şehre anarşi havasını hakim kılmışlardır. ${ }^{44} \mathrm{~Hz}$. Osman ise, Medine gibi haram bir beldede ilk kan döken insan olmak istememiş ve âsilerin silah kullanılarak, bastırılmasına müsaade etmemiştir. ${ }^{45}$

Hz. Osman'1 şehit eden âsiler, temelde siyasete yani fikha ait olan konulardaki ictihat farklılığını tabiî görmeyerek, mecrasından çıkarmışlar ve bunu bir Müslümanın öldürülmesi için sebep kabul etmişlerdir. Aslında Hz. Osman'1n icraatlarında önceki dönemlere göre temelde bir faklılık bulunmamakla birlikte Asr-1 Saadet'ten uzaklaştıkça Müslümanların İslâmî hususlardaki hassasiyetinin yerini dünyevî gayeler almış, özellikle farklı kesimlerden İslâm'a girenler, İslâm'ın ruhuna uymayan düşüncelerin daha çabuk etkisinde kalmışlardı. Nitekim Abdullah b. Ömer, "Hz. Osman'ın tenkit edildiği hususları Hz. Ömer yapmış olsaydı yanlış kabul edilmezdi" ${ }^{46}$ derken, insanlarda ve sosyal şartlarda meydana gelen bu değişime dikkat çekmiştir.

Bir misal olması açısından Hz. Osman'ın bazı icraatlarından hoşnut olmayanların şikâyetçi oldukları konulardan birisi Medine'de bazı yerlerin zekât develeri için koru haline getirilmesiydi. Muhalifler bunun Kur'an'a aykırı olduğunu ileri sürerek: “De ki: Allah'ın size indirdiği; sizin de bir kısmını helal, bir kısmını haram kıldı̆̆ııı rızıklar hakkında ne dersin? De ki: Bunun için Allah mı size izin verdi, yoksa Allah'a iftira mı ediyorsunuz?" 47 âyetini delil göstermişlerdi. Hz. Osman, bu âyetin nasıl nazil olduğunu ve hangi hükümler ihtiva ettiğini onlara anlatıp, kendinden

43 Taberî Târihu'r-rusul ve'l-mülük, IV, 340; İbnü'l-Esir, el-Kâmil fi't-târîh, , III, 46; Yûsuf elIş, ed-Devletü'l-Ümeviyye, Dımaşk 1985, s. 67-9; İsmail Yiğit, “Osman”, DİA, XXXIII, 439.

44 Taberî, a.g.e. IV, 340-1; İbnü'l-Esîr, a.g.e., II, 278-86.

45 İbn Kuteybe, Ebû Muhammed Abdullah b. Müslim, el-İmâme ve's-siyâse, nşr. Tâha Muhammed ez-Zeynî, Kahire 1967, I, 41; Mes'ûdî, Ali b. Hüseyn, Mürûcü'z-zeheb, nșr. Muhammed Muhyiddîn Abdülhamîd, Beyrut 1988, II, 253-254; İbnü'l-Arabi, Ebû Bekir, el-Avâsım mine'l-kavâsım, nşr. Mahmud Mehdî el-İstanbûlî, Beyrut 1987, s. 72,139; İbnü'l-Esîr, a.g.e., II, 277-294.

46 Askalânî, İbn Hacer, Tehzîbü 't-tehzîb, Haydarâbât 1325, VII, 141.

47 Yûnus, $10 / 59$ 


\section{$140 \cdot$ YALOVA SOSYAL BILLIMLER DERGISI}

önce beytülmalin develeri için koruluğu ilk yapanın Hz. Ömer olduğunu bildirerek, onun ictihadına atıfta bulunmuş ve kendisi halife olduktan sonra ise, beytülmalin develeri arttığı için koruluğu genişlettiğini ifade etmiş ve onlar da ikna olmuşlardır. ${ }^{48}$ Aslında bu mesele daha önce Hz. Ömer'in yaptığı gibi ictihadî bir mesele olması itibariyle Hz. Osman'ın bu nevi ictihadlarından dolayı azlini veya öldürülmesini meşru görmek şöyle dursun, tenkit edilmesinin bile İslâmî bir dayanağının olduğunu söylemek mümkün değildir.

Ahmed Cevdet Paşa (1823-1895), Hz. Osman'a yapılan söz konusu itirazların çoğunun ictihad anlayışındaki farklılıktan kaynaklandığına işaret ederek, bu ihtilafların eskiden beri olduğuna dikkat çekmiştir. Ashâbın farklı ictihadları sebebiyle birbirini hatalı görmediğini hatırlatan Cevdet Paşa, Hz. Osman zamanında bazı insanların bu anlayıştan uzaklaştıklarını ve birbirlerini kınamaya başladıklarını ifade ederek, önceden rahmet kabul edilen ictihad farklılıklarının bazı kesimler tarafından tefrika ve fitnenin kaynağı olarak görülmeye başladığına işaret etmiştir. ${ }^{49}$

Hz. Osman'ın şehit edilmesiyle başlayan olaylar etrafında meydana gelen tartışmalarda sonradan itikadî fırkaların görüşlerine temel teşkil eden pek çok mesele gündeme gelmiştir. Bu itibarla Hz. Osman'a isyan eden kişilerin düşünce ve hareketlerinin incelenmesi sonradan ortaya ç1kan ihtilaf ve tefrikanın geri planı ortaya konulması açısından önem arz etmektedir.

Âsiler, hilafetten çekilmesini, aksi takdirde öldüreceklerini söylediği zaman, hilafet makamından çekilmeyeceğini belirten Hz. Osman, hilafet makamını Allah'ın kendine giydirdiği bir gömlek olarak kabul ediyor ve başkaları istedi diye bu gömleği çıkarmayı doğru bulmuyordu. Ayrıca Hz. Osman, bu meseleyi sahâbenin ileri gelenleriyle görüşmüş, onlar da bunu doğru bulmamışlardır. ${ }^{50}$ Kendisiyle istişare edilen sahâbîlerden birisi olan Abdullah b. Ömer (r.a.), Hz. Osman'a "Hilafeti bıraksan dünyada ebedî mi kalacaksın?” demiş ve İslâm'da böyle bir âdeti başlatması durumun-

48 Taberî, Târihu'r-rusul ve'l-mülük, IV, 354; İbn Ebû Şeybe, Ebû Bekir, el-Musannef, Riyad 2004, XIV, 199.

49 Ahmed Cevdet Paşa, Kısas-ı Enbiya ve Tevârih-ı Hulefâ, nşr. M. Muhsin Bozkurt, İstanbul ts. I, 368 .

50 İbn Sa'd, Muhammed, et-Tabakâtü'l-kübrâ, nşr. Ali Muhammed Ömer, Kahire 2001, III, 62.

YIL: 6 SAYI: 11 
da daha sonraları, halifesiyle sıkıntısı olan her toplumun buna teşebbüs ederek, halifeden çekilmesini isteyeceğini belirtmiş ve hilafet makamında kalmasını tavsiye etmiștir. ${ }^{51} \mathrm{Bu}$ itibarla sahâbenin ictihadı, Hz. Osman'ın hal'inin doğru olmadığı yönünde olduğundan bazıları, âsiler ile savaşılması gerektiğini ifade etmişlerdir. ${ }^{52}$ Nitekim sonraki âlimler de ümmetin işlerinin karışıp, Müslümanların zarara uğramasının muhtemel olduğu durumlarda halifenin makamından çekilmesinin caiz olmadığını söylemişlerdir. ${ }^{53}$

Hz. Osman'ın kendi ictihadına dayanan bazı icraatından dolayı âsilerin halifenin azlini istemelerinin özellikle de bunu şiddet kullanarak uygulamaya koymalarının Kur'an'ın bütünüyle doğruluk arz ettiğini söylemek mümkün değildir. Zira Kur'ân'da halifeye genel manada itaat emredilmiş ${ }^{54}$ ve bîati bozmanın kötülüğünden bahsedilmiştir. ${ }^{55}$ Ayrıca Resûlullâh (s.a.v.), halife âdil de, zâlim de olsa, Müslümanların hoşuna gitse de gitmese de mârufu emrettiği müddetçe ona itaat etmeleri gerektiğini beyan etmişlerdir. ${ }^{56}$ Hatta bazı hadislerde, halife, Müslümanların hoşuna gitmeyen davranışlar içerisinde olduğunda, onlara isyan değil, sabır tavsiye edilmiştir. ${ }^{57}$

Söz konusu sebeplerden dolayı, bir halifenin azli için gerekli şartların oluşması durumunda halifenin güç kullanılarak indirilmesi fitneye sebep olup, Müslümanların maslahatına zarar gelecekse, halifeye isyan (hurûc ala’s sultan) caiz görülmemiştir. Böyle bir sakıncanın olmaması durumunda meşruiyetini kaybetmiş bir halifeyi hal' edip yerine hilâfetin şartlarını haiz birisinin getirilmesi gerektiği ifade edilmiştir. ${ }^{58}$

Âsiler arasında yer alan bazı kişiler, Hz. Osman’ı hilafetten çekilmeye zorladıkları sırada onun Kur'ân'a muhalefet etmesi sebebiyle katlinin va-

51 İbn Ebû Şeybe, el-Musannef, XIV, 186.

52 İbn Sa'd, et-Tabakâtü'l-kübrâ, III, 66.

53 Mâverdî, Ebû Hasen Ali b. Muhammed b. Hatib, el-Ahkâmü's-sultâniyye, Beyrut 1990, s. 45; Cüveynî, Ebû'l- Meâli İmâmu'l-Haremeyn Rüknüddîn, el-Glyâsî (Glyâsü'l-ümem fî̀'ltiyâsi 'z-zulem), nşr. Mustafa Hilmî-Fuâd Abdülmü'min, İskenderiye 1979, s.120.

54 en-Nisâ $4 / 59$.

55 el-Fetih 48/18.

56 Buhârî, "Ahkâm”, 4; Müslim, "İmâre”, 51-58.

57 Buhârî, "Ahkâm", 4; Müslim, "İmâre", 8.

58 Gazzâlî, Ebû Hamid Muhammed b. Muhammed, el-íktisâd fi'l-i'tikâd, Kahire 1972, s. 201; Cürcânî, Seyid Şerif, Şerhu'l Mevâkıf, İstanbul ts., II, 467; Teftazânî, Şerhu'l Akâid, s.186. 
cip olduğunu söylemişlerdi. O ise, Resûlullah'ın (s.a.v.) "Bir Müslümanın kanı üç şeyden dolayı mübah olur: irtidat, zina ve haksız yere bir insan öldürmek" ${ }^{59}$ buyurduğunu ve kendisinin bunlardan hiçbirini yapmadığgnı ifade etmiştir. ${ }^{60}$ Onlar ise İslâm'1 bizzat Hz. Peygamber'den öğrenmesi itibariyle Kur'an'1 ve İslâm'1 en doğru şekilde anlayan ve tatbik eden sahâbîlerden birisi olan Hz. Osman'ın açıkladığı İslâmî hükmü kabul etmedikleri gibi ilgili hadisi de dikkate almayarak, kendi görüşlerini teyit etmeye uygun gördükleri âyetleri delil getirme gayretine girmişlerdir. Kendi görüşleri için Sünnet'i dikkate almayarak, sadece Kur'an'dan kaynak bulmaya çalışan âsiler ${ }^{61}$, sürekli Allah'ın kitabına atıfta bulunarak, onunla hüküm verilmesini istemişlerdi. ${ }^{62} \mathrm{~Hz}$. Osman, onlara Allah'ın kitabından deliller getirdiğinde ise hakka tâbi olmamışlar ve kendi görüşlerinde israr etmişlerdir. ${ }^{63}$

Âsiler, Hz. Osman'ın ifade ettiği “bir Müslümanın sadece üç sebepten birisiyle öldürülmesinin caiz olacağını” belirten hadise karşılık, Allah'ın kitabına göre yeryüzünde fesat için çalışan ve bağy (haddi aşmak, devlet otoritesine başkaldırmak) suçunu işleyen kişinin öldürülmesi gerektiğini söylemişler ${ }^{64}$ ve Hz. Osman'1 Allah'ın kitabını tebdil ve tağyir etmekle itham etmişlerdi. ${ }^{65}$ Görüldügü gibi âsiler, Kur'an-1 Kerim'in anlaşılmasında sünneti ve sahâbenin anlayışını dikkate almayarak, sadece kendi görüşlerine uygun gördükleri âyetleri zahirî bir yaklaşımla okuyup, onun üzerine kesin hükümler bina etmek suretiyle ashâbın anlayışından uzaklaşmışlardır.

Âsiler, Hz. Osman'a hilafet makamından çekilme veya öldürülme dişında bir seçenek bırakmamışlar ve daha önce tevbe edip, tekrar günah işlediğini ileri sürerek, tevbe kapısını da kapatmışlardı. ${ }^{66}$ Onlar, bazı âyetleri, siyak ve sibakına bakmadan yani bağlamından koparak, kendi

59 Buhârî, "Diyât", 6; Müslim, "Kasâme", 25.

60 İbn Sa'd, et-Tabakâtü'l-kübrâ, III, 65; İbnü'l-Esir, el-Kâmil fi't-târîh, , III, 61.

61 Taberî, Târihu'r-rusul ve'l-mülük, IV, 354; İbn Asâkir, Ebu'l-Kâsım Ali b. Hasen, Târîhu medineti Dimaşk, Beyrut 1996, XXXIX, 403.

62 İbn Asâkir, Târîhu medineti Dımașk, XXXIX, 411; Zehebî, Șemsüddîn Muhammed b. Ahmed b. Osman, Târihu'l-İslâm ve vefeyâtü'l-meşâhir ve'l-a'lâm, nşr. Ömer Abdüsselâm Tedmürî, Beyrut 1990, III, 443.

63 İbn Kuteybe, el-İmâme ve's-siyâse, s. 69.

64 İbn Sa'd, et-Tabakâtü'l-kübrâ, III, 65; İbnü'l-Esir, el-Kâmil fi t'-târîh, III, 62.

65 İbn Asâkir, Târîhu medineti Dımaşk, XXXIX, 403.

66 İbnü'l-Esir, el-Kâmil fi t'-târîh, III, 60-1.

YIL: 6 SAYI: 11 
görüşlerine delil göstermeye çalışmışlar ve Kur'ân-1 Kerim'in âyetlerini bir bütünlük içerisinde değerlendirmemişlerdir.

Âyetleri siyasî görüşlerine uygun gelecek şekilde yorumlama konusunda Hâricîlere öncülük eden âsiler, Kur'ân-1 Kerim'deki: “De ki: Ey kendilerinin aleyhlerine karşl giden kullarım! Allah'ın rahmetinden ümit kesmeyeniz. Muhakkak Allah, bütün günahları affeder. Şüphesiz O, çok affedicidir ve çok merhamet edicidir" "67 âyetini dikkate almamışlar ve Allah'ın çok geniş olan rahmetini kullarından esirgemişlerdir. $\mathrm{Bu}$ itibarla “Allah'a ve Resûlü'ne savaş açanların ve yeryüzünde fesat çıkarmak için çalışanların cezası, ancak öldürülmeleri yahut asılmaları veya ellerinin ve ayaklarının çapraz olarak kesilmesi yahut o yerden sürülmeleridir. Bu cezalar onlar için dünyadaki bir rezilliktir. Âhirette de onlara büyük bir azap vardır"68 âyetinde beyan edilen hususların aslında âsilerin durumuna uygun olduğu söylenebilir.

Söz konusu âyetin; kâfirler, müşrikler ve mürtedler hakkında nazil olduğu rivayet edilmekle birlikte devlet otoritesine başkaldıran yani halifeye isyan ederek, bâğî durumunda olanlar ve yeryüzünde fesat çıkaran âsiler için de bu hükmün geçerli olduğu ifade edilmiştir. ${ }^{69}$ Fitne ve fesada karş1 mücadele etmeyi mazerete göstererek, halifeyi şehit eden âsiler, İslâm tarihinin en büyük fitnesini çıkarmışlar ve sonradan peş peşe gelen ihtilaf ve kargaşanın neticesinde ortaya çıkan fesadın öncüleri olmuşlardır.

“el-Fitnetü'l-Kübrâ" (en büyük fitne) olarak kabul edilen ${ }^{70} \mathrm{~Hz}$. Osman'ın şehit edilmesi ve onun akabinde gelişen olaylar esnasında Müslümanlar, Asr-1 saâdet'te olmayan pek çok yeni itikâdî mesele ile karş1 karşıya kalmışlardır. Özellikle bir Müslüman'ın bir Müslümanı öldürmesi ve büyük günah işleyen Müslüman'ın durumu ekseninde iman-amel ilişkisi ve tekfir meselesi etrafında farklı görüşler ortaya çıkmıştır. Her şeyden önemlisi Asr-1 saâdet’teki güçlü imana sahip olan samimi Müslümanlar, azalmış ve dünya sevgisini ve makamını ön planda tutan, eski inançlarından tam kurtulamamış insanlar çoğalıp, fitne ve kargaşanın hayat bulacağ 1 bir ortam oluşmuştur. ${ }^{71}$

67 Zümer, 39/53.

68 Mâide, $5 / 33$

69 Mâtürîdî, Te 'vilâtü'l-Kur'an, II, 32.

70 Subhi Sâlih, en-Nüzumu'l-İslâmiyye, Beyrut 1992, s. 263.

71 Hasan Gümüşoğlu, İslâm Mezhepleri Tarihi, İstanbul 2013, s. 47. 


\section{$144 \cdot$ YALOVA SOSYAL BILIMLER DERGISI}

Hz. Osman'ın şehit edilmesinden sonra katillere verilecek cezanın infazı konusunda Müslümanlar görüş ayrılığına düşmüşlerdir. Hz. Ali, katillerin yakalanıp cezalandırılmasının o anda mümkün olmadığını düşündügünden cezalarının ortalığın sakinleşmesine kadar tehir edilmesi yönünde ictihatta bulunmuştur. ${ }^{72}$ Aralarında Hz. Âişe, Hz. Talha, Hz. Zübeyr gibi meşhur sahâbîlerin de bulunduğu bir diğer grup ise, katillerin derhal yakalanıp hemen cezalarının infaz edilmesi gerektiği yönünde ictihad etmişlerdir. ${ }^{73}$ Şam'da Hz. Muâviye ve taraftarları da katillerin bir an önce cezalandırılmasında 1srar etmişlerdir. ${ }^{74}$ Ayrıca Hz. Osman'1n şehit edilmesine son derece üzülen bazı sahâbîler, evlerine çekilmişler, fitne ortamından uzak durmak için siyasî işlere karışmamışlardır. ${ }^{75}$

Âsilerin söz konusu yaklaşımını devam ettiren bir kısım insanlar daha sonra Havâric olarak bilinen firkanın teşekkülüne öncülük etmişlerdir. Hz. Ali, Hz. Osman'1 şehit edenlerin kendisine teslim edilmesini istediğinde; "Osman'1 hepimiz öldürdük"76 diyen âsilerin çoğu, sonradan Haricîlerin arasında yer almıştır. Ayrıca Hz. Osman'ın hilafetinin ilk altı yılından sonra yanlış yaptığı ve katlinin mübah olduğu düşüncesi, Haricîlerin geneli tarafindan kabul edilmiştir. ${ }^{77}$

Cemel ve Sıffîn vak'aları ekseninde meydana gelen olaylarda sahâbenin takındığı tavır ve yaklaşımlar, sonradan ortaya konulan pek çok hükmün esasını teşkil etmiştir. Daha sonraları mezhep ve firkaların görüşlerinin oluşmasında temel ayrılıklardan olan; imâmet meselesi, büyük günah ve bunu işleyen Müslümanın durumu, iman ve amel ile olan ilişkisi gibi konularda Hz. Ali ve diğer sahâbîlerin açıklamaları, verilen hükümlerde belirleyici olmuştur.

72 Bâk1llânî, a.g.e., s. 554; İbnü'l-Esîr, a.g.e., II, 305; İbn Kesîr, Ebû'l-Feda, İsmâil b. Ömer b. Kesîr, el-Bidâye ve'n-nihâye, Beyrut 1966, VII, 228.

73 Mes'ûdî, a.g.e., II, 366; İbnü'l-Esîr, a.g.e., II, 317; İbn Kesîr, a.g.e., VII, 232.

74 İbn Kuteybe, a.g.e., I, 74; İbnü'l-Esîr, a.g.e., II, 359; İbn Kesîr, a.g.e., VII, 228.

75 Nevbahtî, Ebû Muhammed Hasan b. Mûsa b. Hasan, Fıraku'ş-Şîa, Necef 1936, s. 5; Bâkı1lânî, a.g.e., s. 554; Nesefî, Tebsıra, II, 881; İbn Hazm, Ebû Muhammed Ali b. Ahmed, el-Fasl fi'l-milel ve'l-ehvâi ve'n-nihal, nşr. Muhammed İbrahim Nasr-Abdurrahmân U 'meyra, Beyrut 1977, IV, 233.

76 Nasr b. Müzâhim, Vak'atü Suffinn, nşr. Abdüsselâm M. Hârûn, Beyrut 1990, s. 86; ed-Dineverî, Ebû Hanîfe Ahmed b. Dâvûd, el-Ahbârü 't-tıvâl, Kahire 1330, s.165, 172-3

77 İbn Sellâm el-İbâdî, Kitâb fîhi Bed'ul-İslâm ve Şerâiu'd-dîn, nşr. W. Schwartz, Sâlim b. Ya'kûb, Beyrut 1986, s. 105,

YIL: 6 SAYI: $11 \mid$ 


\section{3. İctihad Farklılıklarını Küfür Görme Anlayışı}

Siffîn savaşında meselenin tahkimle çözüme kavuşturulması yönünde tarafların karar almasından rahatsız olan kesim, Hz. Ali'yi tahkimden vazgeçirip savaşa devam etmek istemişlerdi. Hz. Ali, tahkimde israr edince söz konusu topluluk, onun yanından ayrılarak, Hâricîlerin ilk grubunu oluşturdular. ${ }^{78}$ Sıffîn vak'ası esnasında Hz. Ali tarafında bulunan insanların bir kısmına göre, Hz. Osman'ın öldürülmesi meşru olduğundan, Dümetülcendel'de (Ezruh) bir araya gelen hakemler, hilafet konusundan önce bu meseleyi görüşmüşlerdi. Hakemler kimin halife olacağı konusunda anlaşamasalar da Hz. Osman'ın öldürülmesi gereken bir suç işlemediğine ve mazlum olarak öldürüldüğü konusunda görüş birliğine varmışlardı. ${ }^{79}$ Ancak bu karar, Hz. Ali’nin yanında yer alan ve Hz. Osman'ın öldürülmesi gerektiği düşüncesinde olan kesimin rahatsızlığını arttırmıştır.

Hz. Ali'yi önce tahkime zorlayan kişiler, meselenin hallinin hakemlere havale edilmesinden sonra "Hüküm ancak Allah'a aittir" 80 mealindeki âyeti görüşlerine esas yapmışlar ve "Kim Allah'ın indirdiği ile hükmetmez ise işte onlar kâfirlerin tâ kendileridir" "1 âyetini delil getirip, Hz. Ali'yi tekfir etmişlerdir. ${ }^{82}$ Ebu'l-Hasen el-Eşa'rî, Hâricîlerin pek çok konuda kendi aralarında ihtilaf ettikleri halde, tahkimi kabul etmesinden dolayı Hz. Ali'yi tekfir etmekte ittifak ettiklerini belirtir. ${ }^{83}$

Abdullah b. Habbab b. Eret (r.a.) ile karşılaşan Hâricîler, onun boynunda asılı bulunan Kur'an-1 Kerim'e işaret ederek, "senin boynundaki bize seni öldürmeyi emrediyor" demişlerdir. ${ }^{84}$ Abdullah b. Habbab onlara, "İnsanın bedeninin öldüğü gibi kalbinin de öldüğü fitne olacak. Kişi (o zamanda) mümin olarak akşama ulaşır, kâfir olarak sabahlar. (O gün) Allah'ın öldürülen kulu ol, öldüren kulu olma" hadisini okusa da Hâricîler, bu hadisin icabına göre hareket etmemişlerdi. Hâricîler, Abdullah b. Hab-

78 İbn Abdirabbih, Ahmed b. Muhammed, el-ikkdü'l-ferîd, nşr. Müfîd Muhammed Kumeyha, Beyrut 1983, II, 232-3; Nasr b. Müzâhim, Vak'atü Stffin, s. 513,517.

79 Taberî Târihu'r-rusul ve'l-mülük, V, 65; Mes'ûdî, Mürûcu'z-zeheb, II, 308; İsmail Yiğit, "Sıffîn Savaşı", DIA, XXXVII, 108.

80 Yûsuf $12 / 40$

81 Mâide, $5 / 44$

82 Müberred, Ebü'l-Abbâs Muhammed b. Yezîd, el-Kâmil fi'l-lüğa ve'l-edeb, nşr. Muhammed Ahmed ed-Dalî, Beyrut 1997, III, 1079; İbnü'l-Esîr, a.g.e., III, 204.

83 Eş'arî, Ebû'l-Hasen, Makâlâtü 'l-İslâmiyyinn, nşr. Muhammed Muhyiddîn Abdulhamid, Beyrut 1990, I, 167.

84 İbn Abdirabbih, el-ìkd ̈̈'l-ferîd, II, 234. 
bab’a Tahkim Olayı hakkındaki görüşünü sorunca o: "Muhakkak ki Ali (r.a.) Allah'ın kitabını sizden daha iyi bilen, dini üzerine daha fazla takva ve basiret sahibi olan birisidir" demişti. Onlar ise Hz. Ali'nin bu husustaki üstün vasfını inkar ederek, "Sen hidayete tabi olan birisi değilsin. Aksine insanların isimlerine tâbi oluyorsun" 85 demişler ve önce kendisini daha sonra da hamile eşini şehit etmişlerdi.

Hz. Ali, Abdullah Habbab b. Eret'in Hâricîler tarafından şehit edildiğini duyunca haberin doğruluğunu araştırmak üzere Hâris b. Murre el-Abdî’yi göndermiş, ancak o da Hâricîler tarafindan şehit edilmişti. Bunun üzerine bir an önce Hâricîlerin üzerine gitmenin lazım geldiğini düşünen Hz. Ali, onlardan önce katillerin kendisine teslim edilmesini istediğinde onlar: "Hepimiz onların katilleriyiz, hepimiz onların ve sizlerin katlini helal kabul ediyoruz" demişlerdir. ${ }^{86}$

Haricilerin, bazı âyetleri kendi siyasî görüşleri istikametinde yorumlamaları, ictihadın caiz olduğu fikhî meselelerin itikâdî bir boyut kazanmasina sebep olduğundan ihtilafların derinleşerek, tefrikaya dönüşmesinde ve kurumsallaşmasında büyük tesiri olmuştur. İctihadî meselelerin fikhın konusundan çıkarılarak, itikadî alana taşınması, konunun iman-küfür ekseninde tartışılmasına zemin hazırladığından, amelî meseledeki bir hata ve noksanlık Müslümanı tekfir gibi dünyevî ve uhrevî önemli neticeleri olan durumlarla karşı karşıya getirmiştir.

İbn Hazm'1n belirttiği ${ }^{87}$ gibi Ehl-i sünnet arasında itikâdî konulardaki ihtilaf son derece sinırlı olup, fikhî konularda ictihattan kaynaklanan farkl11ıklar ise çok fazla olduğundan itikâdî alanın geniş tutulması hem itikâda taalluk eden ihtilafların çoğalmasına zemin hazırlamış hem de ihtilafların etkisini arttırmıştır. Abdülkerim Şehristânî (548/1153) ise, âlimlerin ictihad mevzuundaki gayretlerinin çokluğuna ve ictihadî meselelerdeki farklı hükümlere dikkat çekmiş ve bu hususlardaki ihtilafın tekfiri gerektiren bir husus olmadığın ${ }^{88}$ ifade ederek, ictihattaki farklılıkların itikadî meselelerden farklı olduğuna işaret etmiştir.

85 Taberî, Târihu'r-rusul ve'l-mülük, V, 82; Müberred, el-Kâmil fi'l-lüğa ve'l-edeb, III, 1134-5; Bağdâdî, el-Fark, s. 77.

86 İbn Ebû Şeybe, el-Musannef, XIV, 287; İbnü'l-Esîr, el-Kâmil fi't-târîh, III, 219.

87 İbn Hazm, el-Fasl, II, 265.

88 Şehristânî, el-Milel ve'n-nihal, I, 246.

YIL: 6 SAYI: 11 
Hz. Ali, Hâricîlerin "Hüküm ancak Allah'a aittir" 89 mealindeki âyeti, kendi görüşlerine temel dayanak yapması üzerine, "kendisiyle bâtılın murat edildiği hak söz"90 demiş ve âyetin yanlış yorumlandığına dikkat çekerek, bu âyetin tahkimin yasaklanmasına delil teşkil etmeyeceğini ifade etmiştir. Âyetlerin Haricîler tarafindan bağlamından koparılarak kendi görüşlerine dayanak yapılmaya çalışıldığını gören Hz. Ali, Abdullah b. Abbas'1 (r.a.) Hâricîler ile mücadeleye gönderirken özellikle Sünnet'ten delil getirmesini istemiş, o da âyetlerin yanı sıra Sünnet'ten bazı deliller getirerek, Hâricîlerle konuşmuş ve onların pek çoğunu ikna etmiştir. ${ }^{91}$

Hz. Ali ve Abdullah b. Abbas, Hâricîler ile görüştükleri zaman onların iddialarına delil olarak gösterdikleri âyetlerin dışında başka âyetleri delil getirip, Hz. Peygamberin sünnetinden örnekler vermişlerdir. Hâricîlerin görüşlerinin temelinde tahkime karşı çıkmak olduğundan, anlaşmazlıkların ortadan kaldırılmasında tahkimin meşru bir usûl olduğu belirtilmiş ve buna delil olarak "Eğer karı kocanın aralarının açılmasından korkarsanız, erkeğin ailesinden bir hakem, kadının ailesinden bir hakem gönderin" âyeti getirilmiştir. ${ }^{93}$ Söz konusu görüşmede ihramlı iken avlanan kimsenin vereceği ceza konusunda âyette geçen "İçinizden adalet sahibi iki kişinin vereceği hüküm"94 şeklindeki beyanına atıfta bulunularak, tahkim konusunun Kur'an-1 Kerim'de yer aldığı belirtilmiş ve Hz. Ömer'in böyle bir meselede Abdurrahman b. Avf'1 hakem tayin ettiğine dikkat çekilmiştir. ${ }^{95}$ Hz. Ali, bunların yanında Benî Kurayza Yahûdileri için verilecek hüküm konusunda Hz. Peygamber'in Sa'd b. Mu'az'1 hakem tayin etmesini hatırlatmış ve bu görüşmelerin sonucunda Hâricîlerden büyük bir kesim görüşlerinden vazgeçmişlerdir. ${ }^{96}$

Hâricîlerin görüşlerine uygun gelecek şekilde bazı âyetlerden elde et-

89 Yûsuf 12/40

90 İbn Abdirabbih, el-ìkdü'l-ferîd, II, 232; İbnü'l-Esîr, el-Kâmil fi't-târîh, III, 213; Şehristânî, el-Milel ve'n-nihal, I, 134.

91 Müberred, el-Kâmil fi'l-lüğa ve'l-edeb, III, 1132-3; İbn Abdirabbih, el-İkdü'l-ferîd, II, 233; Süyûtî, Celâleddîn Abdurrahmân b. Ebû Bekir, el-İtkân fî ulûmi'l-Kur'ân, Kahire 2004, I. 446.

92 Nisâ, 4/35.

93 Taberî, Târihu'r-rusul ve 'l-mülük, V, 64-5; İbn Abdirabbih, el-İkdü'l-ferîd, II, 233; İbnü'l-Esîr, el-Kâmil fi t'târîh, III, 203-4.

94 Mâide, 5/95

95 Müberred, el-Kâmil fi'l-lüğa ve'l-edeb, III, 1080, 1100.

96 Bağdâdî, el-Fark beyne'l-firak, s. 80. 


\section{$148 \cdot$ YALOVA SOSYAL BILLIMLER DERGISI}

tikleri hükümlere itikadî bir renk katmaları ve bundan hareketle de yanlışlarından dolayı sistemli bir şekilde Müslümanları tekfir etmelerinin, Asr-1 Saâdet'te ve sahâbe devrinde hakim olan İslâm anlayışından ayrılmanın açık bir tezahürü olduğu söylenebilir. Nitekim Abdulkâhir el-Bağdâdî(429/1037), Haricîlerden üç fırkanın, günah işleyenlerin küfre gittiklerini iddia ettiğini belirtikten sonra tâbiîn âlimlerinin de içinde bulunduğu Müslümanların büyük ekseriyetinin, büyük günah işleyenlerin mümin olduklarını kabul ettiklerini belirtmiştir. ${ }^{97}$

Hz. Osman'ın şehit edilmesinden sonra cenaze namazının kılınmasına ve bir Müslüman gibi defnedilmesine müsaade edilmemesi dikkate alındığında âsilerin, günahından dolayı öldürülen bir Müslümanı iman ehli görmedikleri söylenebilir. Bununla birlikte âsiler, Hz. Osman'ın öldürülmesi gerektiğini söylemekle birlikte, onu açıkça tekfir etmedikleri halde daha sonra Hâricîler, siyasî alanda ortaya çıkan ictihat faklılı̆̆ını daha da ileri götürüp, itikadî bir boyut kazandırmışlardır. Hâricîler bu tavırlarıyla, tefrikanın kurumlaşmasına zemin hazırlamışlar ve Hz. Ali ve Hz. Osman başta olmak üzer pek çok sahâbînin küfre nispet etmişlerdir. ${ }^{98}$

Hâricîlerin, İslâm dünyasında günah işleyen Müslümanın küfre düştüğünü, onunla savaşılıp öldürülmesi gerektiğini ve tevbe etmeden öldüğü takdirde ebedî cehennemlik olduğunu ${ }^{99}$ sistemli bir şekilde savunan ilk topluluk olduğu söylenebilir. Hâricîlerin bu anlayışı, tarih içerisinde Müslümanların kâfirlerle cihat etmek yerine birbirleriyle mücadelesine sebep olduğundan fitne ve fesadı körükleyen ve Müslümanlar arasında barış ortamını bozan en büyük faktörlerden birisi olmuştur. Hz. Peygamberin günahı sebebiyle bir Müslümanı imandan çıkmış saymadığı ve ona Müslüman muamelesi yaptığı dikkate alındığında bu anlayışın öncelikle Sünnet'e aykırı olduğunu ifade etmek gerekir. Misal olması açısından belirtecek olursak, Hz. Muhammed (s.a.v.), zina gibi büyük bir günahı işlediğini itiraf eden Müslümana recm cezasını tatbik etmekte acele etmeyerek, ona tevbe etmesini söylemiş, cezanın tatbikinden sonra da onun

97 Bağdâdî, a.g.e., s. 117-8.

98 Malâtî, Ebû'l-Heseyn Muhammed b. Ahmed, et-Tenbih ve'r-red alâ ehli'l-ehvâ ve'l-bida, nşr. M. Zahid el- Kevseri, Kahire 1993, s. 50; Bağdâdî, el-Fark beyne'l-firak, s. 72.

99 Eş'arî, Makâlâtü'l-İslâmiyyîn, I, 168; İbn Sellâm Kitâb fỉhi Bedü'l-İslâm ve şerâ'iu'd-dîn, s. 93-4

YIL: 6 SAYI: 11 
cenaze namazını kılmıştır. ${ }^{100}$

Hâricîler, kendilerine muhalif olan her Müslümanın kâfir olduğunu söyleyerek, büyük küçük ayrımı yapmadan onların kanlarının mubah, mallarının helal olduğunu iddia etmişlerdir. ${ }^{101}$ Hâricîler, bu çerçevede iki hakemi ve onların hükümlerini kabul edenleri ve büyük günah işleyen herkesi tekfir edip, kadın veya çocuk ayrımı yapmadan hepsinin öldürülmesini helal görmüşlerdir. ${ }^{102}$ Halbuki "Ĕger müminlerden iki tâife birbirleriyle savaşırsa..." 103 ayetinde beyan edildiği şekilde birbirlerini öldürmek gibi büyük bir günahı işleyen kişiler, "müminler" olarak nitelenmiş ve küfre nispet edilmemiştir. ${ }^{104}$ Belirli âyetlerin dışında İslâm hakkındaki bilgileri oldukça kısıtlı olduğu bilinen Hâricîler, bu bilgisizliklerini sistemleştirmişler ve cehaleti meşru bir mazeret kabul etmişlerdir.

Haricîler, Allah'1 ve Peygamberini, Müslümanların kanının, mal1nın haram olduğunu, gaspın haramlığını bilmeyi ve Allah tarafından yasak edilen konulardan genel manada uzaklaşmayı vacip görerek bunların dışındaki hususları öğrenmeyi zorunlu kabul etmemişlerdir. Hâricîler bu şekilde dinin çok az bir kısmının öğrenilmesini yeterli bulmuşlar ve kesin bilgiye sahip olmadıkları konularda cehaleti geçerli bir mazeret kabul ederek, kısıtlı bilgiye dayanan görüşlerini ictihad olarak değerlendirip, ictihad yoluyla bir kimsenin haramı helal kabul etmesinden dolayı kişinin ma'zur olduğunu söylemişlerdir. Haricîler bu yaklaşımlarıyla avamdan olan bir Müslümanın bilmekle mükellef olduğu bilgiye sahip olmayan kimseleri bile müctehid mertebesine çıkarmakla kalmamışlar, delili bilmediğinden dolayı hükmünde hata eden müctehidin azap görmesinden korkan kişinin bile kâfir olacağını söylemişlerdir. ${ }^{105}$

Haricîlerin Kur'an'a itaate davet ediyor görünmelerine rağmen Kur'an-1 Kerim, onların iddialarını boşa çıkaracak pek çok âyeti ihtiva ettiği gibi, kendi görüşlerini desteklemek maksadıyla öne sürdükleri âyetlerin faklı şekillerde anlaşılması da mümkün olduğundan düşüncelerinin

100 Buharî, "Hudûd", 25; Müslimi "Hudûd" 23.

101 İbn Abdirabbih, el-İkdü'l-ferîd, II, 240.

102 Eş'arî, Makâlâtü'l-İslâmiyyîn, I, 170; Mekkî, Kûtü'l-kulûb, II, 1293; Bağdâdî, el-Fark beyne'l-firak, s. 72; İbn Abdirabbih, el-íkdü'l-ferîd, , II, 240-3

103 Hucurât, 49/9

104 Mekkî, Kûtü'l-kulûb, III, 1293.

105 Eş'arî, Makâlâtü'l-İslâmiyyîn, I, 175. 
çoğunun zannî hüküm ifade eden bir nevi ictihada dayandığı söylenebilir. Onlar kendi ictihadlarına dayalı görüşlerini kesin doğru, diğer Müslümanların görüşlerini ise kesin yanlışlar kabul etmenin ötesinde kendi fikirlerine itikâdî bir boyut kazandırarak, onları kabul etmeyen Müslümanları tekfir etmişlerdir. Halbuki onların ictihat anlayışı pek çok ilmi öğrenmeyi gerektiren ve belirli bir sistem çerçevesinde hüküm istinbat etmeyi zorunlu gören usûl-i fikhın esaslarına dayanmıyordu. İbn Hazm'ın da belirttiği şekilde Hâricîler, sadece Kur'an-1 Kerim'i okuyorlardı ve aralarında Resûlullah'tan (s.a.v.) sabit olan hadisleri anlayan fakih kimseler bulunmadığ için fetva ve ictihad etmenin inceliklerini bilmiyorlard1. Bu sebeple de küçük bir meseleden dolayı Müslümanları tekfir etmekten çekinmemişlerdir. ${ }^{106}$

Hâricîlerin bazısının ictihat ve tekfir konusundaki görüşlerinde zaman içerisinde değişiklikler olmuş, özellikle varlığını günümüze kadar devam ettiren İbâdiyye mensupları zamanla genel manada usûl-i fikhın ilkelerine yakın bir ictihad anlayışına sahip olmuştur. Hâricîlerden İbâdiyye, bazı katı görüşlerini yumuşatarak ve ümmetin genelinin sahip olduğu esaslara yaklaşarak, taraftar bulabilmiş ve varlığını devam ettirebilmiştir. Söz konusu Haricîler, bazı konulardaki faklı yaklaşımlarını devam ettirmekle birlikte, ictihad için aranan şartları ve gerekli ilimleri fakihlerin genel olarak kabul ettiği seviyede zorunlu görmeseler de selefleri gibi sadece bir veya birkaç âyete bakarak hüküm çıkarmak yerine, belirli ilimlere sahip olduktan sonra ictihat etmeyi doğru bulmuşlardır. ${ }^{107}$ Ancak bu yaklaşımı, bütün Haricîlere teşmil etmek, hele tarihteki selefleri hakkında bunu söylemek mümkün değildir. Dolayısıyla Haricîlerin, yeterli ilmî donanımı bulunmayan ve Müslümanları günahı sebebiyle tekfir eden ve onlara en ağır cezaları uygulayan kişiler olduğu, İslam dünyasında genel manada kabul görmüştür.

\section{Tekfir Meselesinde Havâric ve Ehl-i sünnet Arasındaki Anlayış Farklıı̆̆ı}

106 İbn Hazm, el-Fasl, IV, 237.

107 Şemmâhî, Ebu'l-Abbas Ahmed b. Saîd, Kitâbu Muhtasari'l-adl ve'l-insâf, Ummân 1984, s. 45-9.

YIL: 6 SAYI: 11 
Haricîler, "Kim bir mümini kasten öldürürse cezası, ebediyen kalacağ cehennemdir"'108 âyetini delil getirerek, günah işleyen Müslümanın ebedî cehennemlik olduğunu söylemişler ancak bu âyetin doğru anlaşılması için Abdullah b. Abbas'1n "Müslümanı öldürmeyi helal görerek öldürürse" şeklindeki açıklamasını göz ardı etmişlerdir. ${ }^{109}$ Ayrıca "Ĕ̆er müminlerden iki tâife birbirleriyle savaşırsa..." 110 âyetinde birbirlerini öldürmek gibi büyük günah işleyen kişilerin "müminler" olarak nitelenmesini de dikkate almamışlardır.

Ehl-i sünnet âlimler, sahâbe arasındaki ictihad farklılığında Hz. Ali’yi haklı bulmuşlar ancak, "Bir hakim ictihad eder ve verdiği hükümde isabet ederse iki ecir, hüküm verir de ictihadında hata ederse bir ecir vardır" "111 hadisinden hareketle diğer sahâbîlerle ilgili olarak sadece hayırlı șeyler söyleyip, onların adaletli ve güvenilir olduklarını ifade etmişlerdir. Ehl-i sünnet, aralarındaki ictihad farklılığından dolayı sahâbîlerin küfür veya fıska nispetini kabul etmemiştir. ${ }^{12}$ Nitekim Hz. Ali, Cemel vak'ası ile alakalı olarak "Bir topluluk, bizim kendilerine âsi (bâğî) olduğumuza inand1, biz de onların bize karşı âsi olduklarına inandık. Biz bağy (isyan) üzerine savaştık, tekfir üzerine savaşmadık" diyerek, iki tarafın da bir birini küfre nispet etmediğine işaret etmiştir. Ammâr b. Yâsir'e (r.a.) ise Cemel vak'ası sebebiyle Hz. Aişe'nin (r.a.) durumu sorulduğunda o: “Ben kesin olarak biliyorum ki, Hz. Âişe, Resûlullah'ın dünya ve ahirette zevcesidir. Ancak Allah, onunla sizi imtihan etti"'113 cevabını vermiştir. Sıffin'de bir adamın "Şam ehli (Hz. Muaviye tarafında olanlar) kâfir oldu" dediğini duyan Ammâr b. Yâsir, "Öyle konuşma, karşı tarafın peygamberi ile bizim peygamberimiz bir, onların kıblesi ile bizim kıblemiz aynı. Ancak fitneyle karşı karşıya kalıp, haktan ayrıldılar ve bize onları hakka getirinceye kadar savaşmak vacip oldu" ${ }^{114}$ demiştir.

108 en-Nisâ, 4/93.

109 Cüveynî, İmâmü'l-Haremeyn, Ebu'l-Meâlî, Akîdetü'n-Nizâmiyye fi'l-erkâni'l-İslâmiyye, nşr. M. Zâhid Kevserî, Kahire 1992, s. 88.

110 el-Hucurât, 49/9.

111 Buhârî, "İ'tisâm", 21; Müslim, "Akziye", 15; Ebû Dâvûd, "Akziye”, 2.

112 Bâk1llânî, a.g.e., s. 552; İbn Hazm, el-Fasl, IV, 242; Bağdâdî, a.g.e., 121; Nesefî̀, a.g.e., II, 883; Ramazan Altıntaş, "İslam Düşüncesinde Tevhid ve Tefrika", Cumhuriyet Üniversitesi Ilahiyat Fakültesi Dergisi, Sy. I, 1996, s. 118.

113 İbn Abdirabbih, el-İkdü'l-ferîd, V, 79.

114 İbn Ebû Şeybe, el-Musannef, XIV, 270. 
Karşı tarafın Müslüman olduğunu dikkate alan Hz. Ali, kendi tarafında yer alanlardan "karşı taraf saldırmadığı müddetçe savaşa başlamamalarını, kaçıp gidenleri takip etmemelerini, yaralıları öldürmemelerini, mallarını yağmalamamalarını ve kadınlara eziyet etmemelerini”" istemiştir. ${ }^{115} \mathrm{Cemel}$ vak'ası'nda ölen Müslümanların mallarına ganimet muamelesi yapmayan ve onların miras kalan mallarının taksimi konusunda İslam'ın bir Müslümanın mirası için uygulanmasını emrettiği hükümleri tatbik eden Hz. Ali, "Muhalif taraf müşrik midir?” sorusuna "Onlar şirkten uzaklaşanlardır" şeklinde cevap vermiştir. "Onlar münafik mıdır?” denilince de ilgili âyeti ${ }^{116}$ hatırlatarak, "münafiklar Allah'1 çok az zikrederler” demiş, "Peki ya onlar kimlerdir?" denilince "Bize isyan eden kardeşlerimiz"117 diyerek, onları İslâm'dan uzaklaştıracak ifadeleri reddetmiştir. Nitekim Kâdı Ebû Bekir Bâkıllânî, bu açıklamalarına dikkat çekerek, Hz. Ali’nin karşı taraf ile harp etmekle birlikte onları, kâfir ve müşrik görmeyip mümin kabul ettiğinin anlaşıldığgnı belirtmiştir. ${ }^{118}$

Hâricîlerin tekfir etme anlayışı, İslâm dünyasında genel manada kabul görmemiş ve sınırlı sayıda taraftar bulabilmiştir. İctihad farklılıklarına dayanan siyasî ve amelî konulardaki ihtilafı meşru kabul etme ve onlara itikadî bir anlam yüklememe konusundaki sahâbenin tavrını sonraki ulema benimsemiş ve söz konusu meselelerde Müslümanları tekfir etmekten uzak durmuşlardır. Hâricîler, Müslümanları günahları sebebiyle tekfir edip, kanlarını mubah gördüğü halde İmâm-1 Âzam, Havârici tekfir etmeyi doğru bulmamış ve “Onlarla Hz. Ali ve Ömer b. Abdülaziz' in yaptığı şekilde savaşırız” demiştir. "Bağy ehli ile küfürlerinden dolayı değil, isyanlarından dolayı savaşılır” diyen İmâm-ı Âzam'ın bu husustaki şu ifadeleri konu hakkında Ehl-i sünnet'in görüşünü özetlemesi açısından oldukça önemlidir:

"Kim haksız yere birini öldürür, hırsızlık eder, yol keser yahut fisk veya fücûr işler, zina eder, içki içer sarhoş olursa; bu kişi fâsık mümindir, kâfir değildir. $\mathrm{Bu}$ sebeple onlar günahlarından dolayı cehennemde azap görür, imanları sebebiyle cehennemden çıkar." 119

115 Taberî, Târihu'r-rusul ve'l-mülük, V, 11; Bakıllânî, et-Temhîd, s. 556.

116 Nisâ, 4/142

117 İbn Ebû Șeybe, el-Musannef, XIV, 240.

118 Bakıllânî, et-Temhîd, s. 557.

119 İmâm-1 Âzam, el-Fikhu'l ebsat, s. 53-4.

YIL: 6 SAYI: 11 
F1khın ictihada dayalı konularında tekfiri doğru bulmayan Ehl-i Sünnet âlimler, âyetlerde belirtilen "bilerek bir Müslümanı öldüren” veya "Allah'ın indirdiği ile hükmetmeyen" ${ }^{120}$ kimselerin küfre nispet edilmesinin "istihlâl" durumunda geçerli olduğunu söylemişlerdir. ${ }^{121}$ Ebû Hamid Gazzâlî (ö.505/1111), yolları farklı da olsa "Allah’tan başka ilah yoktur, Muhammed (s.a.v.) Allah’ın peygamberidir” sözüne sadık kalıp, bu sözü nakzetmeyip, ona tutunmaya devam eden Müslümanın küfre nispet edilmesinden kaçınılması gerektiğini söylemiştir. İctihada dayalı meselelerde faklı görüşlere sahip olması sebebiyle bir Müslümanın tekfir edilmesini doğru bulmayan Gazzâlî, "imanı, Hz. Muhammed'i (s.a.v.) getirdiği bütün hususlarda tasdik etmek" şeklinde tarif ederek, amelin Hz. Peygamberi tekzip eden bir durum olmadığı müddetçe küfre sebep olmayacağına işaret etmiştir. Küfür ve tekfir meselesinin, Müslümanın kanını mubah kılma ve cehenneme gitme gibi dünyevî ve uhrevî sonuçlarını dikkate alan Gazzâlî, konunun dinî bir hüküm olduğunu belirterek, kesin bir delil ve sarih bir beyan bulunmadan tekfirden uzak durulması gerektiğini ifade etmiştir. ${ }^{122}$

\section{Sonuç}

Kur'ân-1 Kerim ve Sünnet, İslâmî hükümlerin temel kaynağı olmakla birlikte bunlarda yer almayan mevzularda veya bu naslara dayalı olarak meselelerin dinî hükmünün belirlenmesinde ictihadın önemli bir yeri olduğu anlaşılmaktadır. Bu sebeple Asr-1 saâdet ve sahâbe devrinde pek çok meselede ictihat yapıldığ 1 gibi aynı meselede farklı ictihatların ortaya çıktığ1 da görülmüştür. İctihada mahal olan mevzularda her müctehidin aynı görüşe sahip olması, bir mecburiyet olarak görülmediğinden bu durum meşru olarak kabul edilmiş hatta fikhî mevzularda farklı ictihadlar bir zenginlik olarak görüldügünden bu konudaki ihtilaflar tenkit konusu yapılmamıştır. Ancak Hz. Osman'ın şehit edilmesiyle sonuçlanan olayların başlamasından sonra bu yaklaşımda bir kırılmanın yaşandığı dikkat çekmektedir.

120 Mâide, 5 /44

121 Mâtürîdî, Kitâbü't-Tevhid, s. 348; Mekkî, a.g.e., II, 209; Cürcânî, Şerhu'l-Mevâkîf, II, 458, Teftazânî, Şerhu'l-Makâsîd, V, 203; a. mlf., Şerhu'l-Akâid, s. 142-4; Aliyyü'l-kârî, Şerhu'lF1kh1'l-ekber, s. 226.

122 Gazzâlî, Faysalü 't-Tefrika, “Mecmuatu Resâili'l-İmam el-Gazzâlî”, s. 78-98. 


\section{$154 \cdot$ YALOVA SOSYAL BILLIMLER DERGISI}

Siyasete yani fikha ait olan ve ictihat farklılığına dayanan konuları bağlamından koparan âsiler, bunu bir Müslümanın öldürülmesi için sebep kabul etmişler ve temelde ictihadlarına dayanan icraatlarından dolayı Hz. Osman'1 şehit etmişlerdir. Bir Müslümanı günahından dolayı öldürme şeklinde ifade edilebilecek bu yaklaşım, Kur'an ve Sünnet'e dayalı İslâm anlayışından toplumsal temelde kopuşun ilk örneği olarak değerlendirilebilir. Âsiler, Hz. Osman'1n öldürülmesi gerektiğini söylemekle birlikte, onu açıkça tekfir etmedikleri halde Hâricîler, siyasî alanda ortaya çıkan ictihat faklılığını daha da ileri götürüp, itikadî bir boyut kazandırarak, tefrikanın kurumlaşmasına ön ayak olmuşlar ve Hz. Ali'nin yanı sıra Hz. Osman'ın da küfre gittiğini iddia etmişlerdir. İnanmak ve kalben tasdik etmekle alakalı hususları ihtiva eden itkadî sahanın içine ictihadın mubah olduğu amele ait hususların dahil edilmesi meselenin faklı bir mecrada gelişmesine sebebiyet vermiştir.

Hz. Ali, karşısında yer alan tarafın âsi olduklarını söylemekle birlikte bu günahlarından dolayı onların tekfir edilmesine karşı çıkmış, siyasetin dolayısıyla fikhın alanına giren ve ictihada mahal olan konuların itikadî alana taşınarak, Müslümanların küfre nispet edilmesini doğru bulmamıştır. Âlimlerin ekseriyeti, ictihad farklılığından dolayı Müslümanların küfre nispet edilmesini yanlış bulmuşlardır.

\section{Kaynakça}

Abdülazîz el-Buhârî, Keşfü'l-esrâr an Usûli Fahri'l-İslâm Pezdevî, nşr. Abdullah Mahmûd Muhammed Ömer, Beyrut 1997

Aclûnî, İsmâil b. Muhammed, Keş̧ü'l-hafâ', Kâhire 1351

Ahmed Cevdet Paşa, Kısas-ı Enbiya ve Tevârih-ı Hulefâ, nşr. M. Muhsin Bozkurt, İstanbul ts

Aliyyü'l-kârî, Şerhu'l-Fıkhı'l-ekber, Beyrut 1984

Altıntaş, Ramazan, "İslam Düşüncesinde Tevhid ve Tefrika", Cumhuriyet Üniversitesi Illahiyat Fakültesi Dergisi, Sy. I, 1996

Âlûsî, Şihâbüddin Mahmud, Rûhu'l-Maânî, Beyrut 1998

Âmidî, Seyfüddîn Ali b. Muhammed, el-İhkâm fî usûli'l-ahkâm, nşr. Abdurraz- 
İCTIHAD FARKLILIKLARININ ITIKÂDÎ BOYUT KAZANMASININ SONUÇLARI HÂRICÎLER ÖRNEC̆i • 155 zâk Afîfî, Riyad 2003

Askalânî, İbn Hacer, Tehzîbü 't-tehzîb, Haydarâbât 1325

Bâkıllânî, Kâdı Ebû Bekir Muhammed b. et-Tayyib, et-Temhîd, nşr. İmâdüddîn Amed Haydar, Beyrut 1987

Bağdâdî, Ebû Mansûr Abdulkâhir b. Tahir et-Temimî, el-Fark beyne'l-firak, Beyrut 1990 , Usûlü'd-dîn, Beyrut 1981

Beyakî, Ebû Bekr Ahmed b. Hüseyn b. Ali, es-Sünenü'l-kübrâ, Hindistan 1355 , Delâilü’n-nübüvve, nşr. Abdülmu’tî Kal'acî, Kahire 1988 , el-Medhal ila 's-Süneni 'l-kübrâ, nşr. Muhammed Ziyâürrahmân el-A'zamî, Riyad 1420

Bozkuş, Metin, "İslâm Mezhepleri Açısından Dini Düşüncenin Geçirdiği Evreler", Cumhuriyet Üniversitesi İlahiyat Fakültesi Dergisi, Sy., VI/I, 2002

Cessâs, Ebû Bekr Ahmed b. Alî er-Râzî, el-Füsûl fi'l-usûl nşr. Uceyl Câsim en-Neşemî, Kuveyt 1994

Cürcânî, Seyyid Şerîf, et-Ta 'rifât, nşr. Abdurrahmân Umeyra, Beyrut 1987

, Şerhu'l Mevâkıf, İstanbul ts.

Cüveynî, Ebû'l-Meâli İmâmu'l-Haremeyn Rüknüddîn, el-İrşâd ilâ kavâtı ‘̀l-edille fi usûli'l-i 'tikâd, nşr. Esad Temimî, Beyrut 1992 , el-Glyâsî̀ (Gıyâsü'l-ümem fî'ltiyâsi'z-zulem), nşr. Mustafa Hilmî-Fuâd Abdülmü'min, İskenderiye 1979

, Akîdetü'n-Nizâmiyye fi 'l-erkâni'l-İslâmiyye, nşr. M. Zâhid Kevserî, Kahire 1992

Dineverî, Ebû Hanîfe Ahmed b. Dâvûd, el-Ahbârü 't-tıvâl, Kahire 1330

Eş'arî, Ebu'l-Hasen, el-İbâne an usûli'd-diyâne, nşr. Abbas Sabbağ, Beyrut 1994 , Makâlâtü'l-İslâmiyyîn, nşr. Muhammed Muhyiddîn Abdulhamid, Beyrut 1990

Fîrûzâbâdî, Mecdüddîn Ebû Tâhir Muhammed b. Ya'kûb, Kâmus Tercemesi, trc. Asım Efendi, İstanbul 1304

Gazzâlî, Ebû Hamid, el-Müstasfâ min ilmi'l-usûl, nşr. Hamza b. Züheyr Hâfız, Medine, 1993 , Faysalü t-tefrika, Beyrut 1994 
$156 \cdot$ YALOVA SOSYAL BILIMLER DERGISI

, Kavîdü'l-akâid, Beyrut ts.

Gümüşoğlu, Hasan, İslâm Mezhepleri Tarihi, İstanbul 2013

, "İmanın Artması-Eksilmesi Meselesi ve Amel ile İlişkisi”, Diyanet İlmi Dergi, c. 44, Sy. II (2008)

İbn Abdirabbih, Ahmed b. Muhammed, el-İkdü'l-ferîd, nşr. Müfîd Muhammed Kumeyha, Beyrut 1983

İbn Âbidîn, Muhammed Emîn, Reddü'l-muhtâr ale'd-Dürri'l-muhtâr şerh Tenvîri'l-ebsâr, nşr. Âdil Ahmed Abdülmevcûd-Ali Muhmmed Muavvız, Kâhire 1994,

İbn Abdilber, Ebû Ömer Yusuf, Câmiu beyâni'l-ilm ve fazlihi, nşr. Ebu'l-Eşbâl ez-Züheyrî, Demmam 1994

İbn Asâkir, Ebu'l-Kâsım Ali b. Hasen, Târîhu medineti Dımaşk, Beyrut 1996

İbn Ebî Ya'lâ, Ebû Hüseyn Muhammed, Tabâkâtu'l-Hanâbile, nşr. Abdurrahmân b. Süleymân, Riyad 1419

İbn Ebû Şeybe, Ebû Bekir, el-Musannef, Riyad 2004

İbn Haldun, Abdurrahman b. Muhammed, Mukaddime, Beyrut 1992

İbn Hazm, Ebû Muhammed Ali b. Ahmed, el-ỉhkâm fì usûli'l-ahkâm, nşr. Ahmed Muhammed Şâkir, Kahire ts.

, el-Fasl fi'l-milel ve'l-ehvâi ve'n-nihal, nşr. Muhammed İbrahim Nasr-Abdurrahmân U'meyra, Beyrut 1977

İbn Hişâm, es-Sîretü'n-Nebeviyye, nşr. Mecdî Fethî es-Seyyid, Tanta 1995

İbn Kesîr, Ebû'l-Feda, İsmâil b. Ömer b. Kesîr, el-Bidâye ve'n-nihâye, Beyrut 1966

İbn Kudâme, Muvaffakuddîn el-Makdisî, Lüm 'atü'l-i 'tikâd, Beyrut 1395

İbn Kuteybe, Ebû Muhammed ed-Dîneverî, Te'vîlü muhtelifi'l-hadîs, nşr. Ebû Üsâme Selîm, Kahire 2009

İbn Kuteybe, Ebû Muhammed Abdullah b. Müslim, el-İmâme ve's-siyâse, nşr. Tâha Muhammed ez-Zeynî, Kahire 1967

İbn Manzûr, Lisânü'l-Arab, Beyrut 1994

İbn Sa'd, Muhammed, et-Tabakâtü'l-kübrâ, nşr. Ali Muhammed Ömer, Kahire 2001

İbn Sellâm el-İbâdî, Kitâb fỉhi Bed'ul-İslâm ve Şerâiu'd-dîn, nşr. W. Schwartz,

YIL: 6 SAYI: 11 
ICTIHAD FARKLILIKLARININ ITIKÂDÎ BOYUT KAZANMASININ SONUÇLARI HÂRICÎLER ÖRNEĞi • 157

Sâlim b. Ya'kûb, Beyrut 1986

İbnü'l-Arabi, Ebû Bekir, el-Avâsım mine'l-kavâsım, nşr. Mahmud Mehdî el-İstanbûlî, Beyrut 198

İbnü'l-Esîr, İzzeddîn Ebi'l-Hasen Ali b. Ebi'l-Kasım eş-Şeybânî, el-Kâmil fi 'ttârîh, Beyrut 1987

İmam-1 Âzam, Ebu Hanife, el-Fıkhu'l-ekber, nşr. Mustafa Öz, İstanbul 1992 , el-Fıkhu'l-ebsat, nşr. Mustafa Öz, İstanbul 1992

, Risâle ilâ Osman el-Bettî, nşr. Mustafa Öz, İstanbul 1992

İmâm-ı Rabbânî, Mektûbât, İstanbul ts.

İsmail Hakkı İzmirli, Yeni İlm-i Kelâm, Dersaâdet 1330

Kâd1 Abdülcebbâr, Şerhu'l-usûli'l-hamse, Beyrut 2001

Kurtubî, Ebû Abdullah Muhammed b. Ahmed, el-Câmi' li-ahkâmi'l-Kur'ân, Beyrut 2006

Lâlekâî, Hibetullah b. el-Hasen b. Mensur, Şerhu-usûli-i'tikâdu Ehli s-sünne ve'lcemâa, Beyrut 2007

Malâtî, Ebû'l-Heseyn Muhammed b. Ahmed, et-Tenbih ve'r-red alâ ehli'l-ehvâ ve 'l-bida, nşr. M. Zahid el- Kevseri, Kahire 1993

Mâtürîdî, Ebû Mansûr Muhammed, Te'vîlâtü Ehli s-sünne, nşr. Fatıma Yusuf el-Hiyamî, Beyrut 2004

, Kitâbü 't-Tevhîd, nşr. Fethullâh Huleyf, İskenderiye ts.

Mâverdî, Ebû Hasen Ali b. Muhammed b. Hatib, el-Ahkâmü's-sultâniyye, Beyrut 1990

Mekkî, Ebû Tâlib, Kûtü'l-kulûb, Beyrut 1997

Mes'ûdî, Ali b. Hüseyn, Mürûcü'z-zeheb, nşr. Muhammed Muhyiddîn Abdülhamîd, Beyrut 1988

Molla Hüsrev, Mirâtü 'l-Usûl, İstanbul 1310

Müberred, Ebü'l-Abbâs Muhammed b. Yezîd, el-Kâmil fi'l-lüğa ve'l-edeb, nşr. Muhammed Ahmed ed-Dalî, Beyrut 1997

Münâvî, Muhammed Abdurraûf, Feyzü'l-kadîr şerhu'l-Câmiu's-sağîr, Beyrut 1994

Nasr b. Müzâhim, Vak'atü Siffinn, nşr. Abdüsselâm M. Hârûn, Beyrut 1990 


\section{$158 \cdot$ YALOVA SOSYAL BILLIMLER DERGISI}

Nesefî, Ebü'l-Muîn Meymun b. Muhammed, Tebsıratu'l-edille fî usûli'd-dîn, nşr. Claude Salâme, Dımaşk, 1993

Nevbahtî, Ebû Muhammed Hasan b. Mûsa b. Hasan, Fıraku'ş-Şîa, Necef 1936

Nevevî, Ebû Zekeriyyâ Yahyâ b. Şeref, el-Minhâc fî şerhi Sahîhi Müslim b. Haccâc, Kahire 1930

Râzî, Fahreddîn Muhammed b. Ömer b. Hüseyn, el-Mahsûl fì ilmi usûlü'l-fikh, nşr. Tâhâ Câbir Feyyâz el-Ulvânî, Beyrut 1992

,Mefâtihu'l-gayb, Beyrut ts

Serahsî, Şemsüleimme, Ebû Bekr Muhammed b. Ebî Sehl Ahmed, Usûlü s-Serahsî, nşr. Ebu'l-Vefâ el-Efgânî, Beyrut 1993 , el-Mebsût, Beyrut 1989

Süyûtî, Celâleddîn Abdurrahmân b. Ebû Bekir, el-İtkân fì ulûmi 'l-Kur'ân, Kahire 2004

Şâfîi, Ebû Abdullâh Muhammed b. İdris, el-Üm, nşr. Rif'at Fevzî Abdülmuttalib, Mensûre 2001

Şa'rânî, Abdulvahhâb b. Ahmed, el-Yevâkît ve'l-cevâhîr, Kahire, 1959

Şehristânî, Ebu'l-Feth Muhammed b. Abdilkerîm, el-Milel ve'n-nihal, nşr. Abdulemîr Ali Mehnâ-Ali Hasan Fâ ur, Beyrut 1993

Şemmâhî, Ebu'l-Abbas Ahmed b. Saîd, Kitâbu Muhtasari'l-adl ve'l-insâf, Ummân 1984

Şemseddîn Sâmî, Kâmus-ı Türkî, Dersaâdet 1317

Tabarânî, Ebü'l-Kâsım Müsnidü'd-dünyâ Süleymân b. Ahmed b. Eyyûb, Mu'cemü'l-kebîr, nşr. Hamdî Abdülmecid es-Selefî, Kahire ts.

et-Taberî Ebû Câfer Muhammed b. Cerir, Târihu'r-rusul ve'l-mülük, Kahire ts.

Teftâzânî, Sa duddîn Mes ud b. Ömer, Şerhu't-Telvîh, alâ't-Tevzîh li Metni 't-Tenkîh, Dâru'l-kütübi'l-ilmiyye, Beyrut ty.

, Şerhu'l-Akâid, Dersaâdet 1326

, Şerhu'l-Makâsıd, nşr. Abdurrahman U 'meyrâ, Beyrut 1989

İsmail Yiğit, "Osman”, DİA, XXXIII

Yûsuf el-Iş, ed-Devletü'l-Ümeviyye, Dımaşk 1985

Yücedoğru, Tevfik, "İtikâdî İlkelerin Tespiti”, Selçuk Üniversitesi Illahiyat Fakültesi Dergisi, c. XIX, Bahar 2005 
ICTIHAD FARKLILIKLARININ ITIKÂDî BOYUT KAZANMASININ SONUÇLARI HÂRICÎLER ÖRNEĞi • 159

Zehebî, Șemsüddîn Muhammed b. Ahmed b. Osman, Târihu'l-İslâm ve vefeyâtü'l-meşâhir ve'l-a 'lâm, nşr. Ömer Abdüsselâm Tedmürî, Beyrut 1990 